\title{
Seasonal and Interannual Variability of the North-Western Black Sea Ecosystem
}

\author{
Joanna Staneva ${ }^{1,2, *}$, Villy Kourafalou ${ }^{3}$, and Kostas Tsiaras ${ }^{4}$ \\ ${ }^{1}$ Institute for Coastal Research, GKSS Research Center, D-21502 Geesthacht, Germany \\ ${ }^{2}$ ICBM, University of Oldenburg, Postfach 2503, D-26111 Oldenburg, Germany \\ ${ }^{3}$ Rosenstiel School of Marine and Atmospheric Science, University of Miami, Miami, FL 33149-1098, USA \\ ${ }^{4}$ Hellenic Center for Marine Research, Anavissos, 19013, Greece
}

Received 16 December 2008, accepted 8 June 2009

\begin{abstract}
This study describes the coupling between physical and biogeochemical models and analyses the response of the ecosystem in the north-western Black Sea to nutrient loads and climate changes. The basic physical and biological dynamics of the upper north-western Black Sea is illustrated as well. The physical model is based on the Princeton Ocean Model (POM); additionally, a parameterisation of mixed layer is included. The biogeochemical model is based on the European Regional Sea Ecosystem Model (ERSEM) and consists of five modules: (1) primary producers, (2) microbial loop, (3) mesozooplankton, (4) benthic nutrients, and (5) benthic biology. The ecosystem in ERSEM is subdivided into three functional types, producers (phytoplankton), decomposers (pelagic and benthic bacteria) and consumers (zooplankton and zoobenthos). Model-data comparisons have been performed for both calibrating and verifying coupled model simulations. We address here the impact of nutrient discharge from the Danube River on the functioning of the biological system. The evolution of the mixed layer, as well as the response of the biological system to variability of the nutrient discharge from the Danube River is described in detail. Several scenarios have been developed to study the impact which nutrient reduction has on the coastal marine system. The model predictions indicate that the biological system is very sensitive to the changes in nutrient concentrations, as well as to their ratios.
\end{abstract}

Key words: Black Sea, Numerical modelling, Coastal zone, Ecosystem dynamics, Impact of anthropogenic activities

Citation: Staneva, J., V. Kourafalou, and K. Tsiaras, 2010: Seasonal and interannual variability of the north-western Black Sea ecosystem. Terr. Atmos. Ocean. Sci., 21, 163-180, doi: 10.3319/TAO.2009.06.08.03(IWNOP)

\section{INTRODUCTION}

The Black Sea ecosystem has experienced substantial changes since the 1960 s, driven by several perturbations in the drainage basin of the rivers and the Black Sea itself. Among the different characteristics of the recent man-made impact on the Black Sea (land use changes differentiating the river nutrient load of $\mathrm{PO} 4$ and $\mathrm{NO} 3$, as compared to $\mathrm{Si}(\mathrm{OH})$; changes of hydrological regimes of out-flowing rivers; introduction of exotic species, i.e., the gelatinous Ctenophore Mnemiopsis; and selective or excessive fishing), we still do not know which is the most important in terms of largescale biological and ecological consequences and what the synergy between the different human activities and the natural forcing would be. We focus on the effects of changes

\footnotetext{
* Corresponding author

E-mail: joanna.staneva@gkss.de
}

in the nutrient loads from the Danube River (both in nutrient content and quality), which we expect to play a significant role on the functioning of the Black Sea ecosystem.

The synergy between the different human forcing cannot be assessed from simple correlations between ecological observations and historical correlations. The biogeochemical models provide a powerful tool for studying the biological and chemical compartments as a function of physical and human impacts. As a mathematical tool for studying recent eutrophication-related ecosystem changes of the northwestern Black Sea we use here the European Regional Seas Ecosystem Model (ERSEM) coupled with the three dimensional Princeton Ocean Model (POM) and a onedimensional mixed layer model, forced by daily records of Danube nutrients concentrations at the river outflow. The effect of nutrient discharge on the quality of a given ecosystem is tested by looking at the ecosystem behaviour in several 
periods, characterised by different nutrient discharge rates.

A hierarchy of models have been used to study the ecological functioning of the Black Sea. Several ecological models were developed for the surface layer of the Black Sea (Oguz et al. 1996; Grégoire et al. 1997; Staneva et al. 1997; Cokasar and Ozsoy 1998; Oguz et al. 1999; Lancelot et al. 2002). Some of them used very simplified physics (e.g., the evolution of the mixed layer depth only) and studied the ecological processes as averaged within the surface mixed layer (Eeckhout and Lancelot 1997; Oguz et al. 2001; Lancelot et al. 2002). There are some studies in which the ecological model is coupled with a 3-dimensional hydrodynamical model (e.g., Grégoire et al. 1997; Oguz and Salihoglu 2000; Staneva et al. 2003; Grégoire et al. 2004; Tsiaras et al. 2008).

In this paper we apply for the first time ERSEM in the Black Sea. ERSEM was originally developed by Baretta et al. (1995), and used extensively for the North Sea (e.g., Allen et al. 1999, see also the references in the model description section). Several further developments and applications of ERSEM for other European seas have been implemented as well (for the Adriatic Sea, see Vichi et al. 2003a, b). Since we apply ERSEM in the Black Sea region for the first time, careful model tuning and validations with observations have been performed. Therefore we will discuss the agreement between the model and observations over a seasonal cycle, before accessing the problems of the sensitivity of the ecosystem to river input.

A hierarchy of observational data have been used for tuning and verifying the model. Climatological data set have been prepared by the use of almost all historical observational measurements for the north-western Black Sea. In the period from 2001 to 2004 extensive observations have been performed in the frame of EU FP6 DANUBS (DAnube NUtrient management and its impact on the Black Sea) Project (see http://danubs.tuwien.ac.at/). We refer also to the project reports for more information about the all tuning and verifications experiments. Nevertheless, in this paper we present the final set of parameters as well as a brief discussion on the most important parameters that needed to be tuned to apply ERSEM for the north-western Black Sea environment.

The paper is organized as follows. The models used in this study are described in section 2. Model to data comparisons have been analysed in section 3 . The response of the ecosystem to changing the nutrient discharge is discussed in section 4 and we end with a conclusion.

\section{MODEL DESCRIPTION}

\subsection{Physical Model}

The hydrodynamic model is based on the Princeton Ocean Model (POM) (Blumberg and Mellor 1983) which is a 3-dimensional, sigma-coordinate, primitive equation and free-elevation model with a 2.5 turbulence closure submodel
(Mellor and Yamada 1982) which calculates vertical eddy viscosity/diffusivity taking account of the wind stirring and the stratification of the column. The model output includes the 3-D velocity field, temperature, salinity and free surface elevation. The model has been modified to include river plume dynamics, following the approach developed by Kourafalou et al. (1996). This is a key model modification that allows the detailed description of the development and evolution of the Danube River plume. The high resolution $(\sim 5 \mathrm{~km})$ hydrodynamic shelf model is nested to a lower resolution $(\sim 10 \mathrm{~km})$ basin scale model, which provides the necessary open boundary conditions (for more details see Kourafalou et al. 2004). Sixteen sigma levels are resolved in the vertical with logarithmic distribution approaching the surface. In order to increase the vertical resolution in the open Black Sea, permitting a better simulation of the mixed layer dynamics, that are particularly important for the ecosystem simulation, a maximum water depth of $500 \mathrm{~m}$ has been employed. The initial density field and climatological atmospheric fluxes are provided by a long-term climatological run of a basin scale model which is based on the Modular Ocean Model (MOM, Staneva et al. 1997). Using the above climatological atmospheric fluxes and average Danube discharge rates (1994 - 2002) a 1-year long climatological type simulation was performed by the shelf model, providing initial conditions for a "realistic" simulation where 6-hour atmospheric forcing and one-day Danube discharge rates are employed for the period 2002 - 2003. This simulation is the base for our scenario simulations. Daily Danube discharge rates and nutrient inputs were calculated for this period by a model of the Danube Delta (Constantinescu and Menting 2000; Van Gils et al. 2005).

\subsection{Mixed Layer Model}

The mixed layer model embedded into the coupled physical-biogeochemical model is based on the formulation of Gill and Turner (1976), relating the changes in the potential energy of a vertical water column to the rate of wind stress at the sea surface. The model is based on the principles of energy conservation. Convection in the model is partly penetrative with 85 percent of convectively generated turbulent kinetic energy dissipated within the mixed layer. The penetrative short wave flux is represented by a double exponential decay function. The mixed layer model calculates density changes resulting from changed temperature and salinity. This makes it possible to estimate the work done to increase its potential energy. The main part of the model realises the vertical mixing, which can be either due to instability, or to available mechanical energy by wind. The model parameters were chosen such that the ranges of simulated mixed layer depth lie in the ranges given from observations (e.g., Staneva et al. 1997). The forcing functions of the mixed layer model are: the penetrative (solar) com- 
ponent of surface flux; the non-penetrative heat flux (this contributes to the heating of the top layer) and the mechanical ("wind mixing") energy, which is available for mixing water in the stable stratified column. The mixed layer model is forced with the fluxes (wind stress, heat and freshwater) diagnosed by the basin-wide hydrodynamical model (see also Stanev et al. 1997; Staneva and Stanev 1998).

\subsection{Ecosystem Model}

As described in the introduction, we use in this study the European Regional Seas Ecosystem Model (ERSEM, Baretta et al. 1995). ERSEM consists of five modules: the primary producer module; microbial loop module; mesozooplankton module; benthic nutrients module and benthic biology module. State variables in ERSEM have been chosen in order to keep the model relatively simple without omitting any component that exerts a significant influence upon the energy balance of the system (Allen et al. 1999). The dynamics of the biological functional groups are described by both physiological (inhale/exhalation, ingestion, excretion and large matter expulsion) and population processes (growth, migration and mortality). Detailed descriptions of the biological sub-models can be found for: phytoplankton in Varela et al. (1995) and Ebenhöh et al. (1997); functional groups related to the microbial food web in BarettaBekker et al. (1997a); mesozooplankton in Broekhuizen et al. (1997); fish in Bryant et al. (1995) and benthic fauna in Baretta-Bekker et al. (1997b) and Blackford and Radfort (1997). The dynamics of the biological functional groups are described by both physiological (ingestion, respiration, excretion and egestion) and population processes (growth, migration and mortality). The ecosystem in the ERSEM is subdivided into three functional types: producers (phytoplankton), decomposers (pelagic and benthic bacteria) and consumers (zooplankton and zoobenthos). More details about the processes included can be found in the above mentioned references.

The particular application of ERSEM in the north-western Black Sea includes a unique development in the framework of the DANUBS project, namely its three-dimensional coupling with the POM hydrodynamic model (see section 2.1), which includes river plume dynamics. Thus, ERSEM has been forced with water and nutrient inputs from the Danube River and computes distributions of ecosystem variables that are largely influenced by the variability of these inputs, in the context of the prevailing hydrodynamic and biological processes.

\subsection{Coupled Model Initialisation, Forcing and Para- meters}

At the sea surface we use atmospheric analyses data, provided by the POSEIDON operational system (Papado- poulos et al. 2002; http://www.poseidon.ncmr.gr/) and bulk parameterization formulas (Staneva and Stanev 1998) to estimate the wind stress component, radiative flux, heat and freshwater fluxes. Non-slipping boundary conditions are assumed at the bottom. The atmospheric fluxes for the biogeochemical variables are set to zero. For estimating the lateral fluxes we use the procedure described in Lenhart et al. 1997). Similar techniques have already been used successfully for the north-western Black Sea box simulation with BIOGEN model (Beckers et al. 2002; Lancelot et al. 2002). For a more detailed technical description of the equations giving the connection between a sigma-coordinate hydrodynamic model and the mixed-layered model for the northwestern shelf Black Sea we refer to these papers.

The initial conditions for the biogeochemical components are prepared from the observed data provided by A. Cociasu (personal communications). The initial conditions for temperature and salinity are taken from POM simulations (Kourafalou et al. 2004; Tsiaras et al. 2008). The vertical diffusion coefficients are estimated using stability dependency (see Staneva and Stanev 2002). We assume zero sea surface fluxes from the biogeochemical state variables.

The ERSEM set-up follows that of Vichi et al. (2003a, b). Therefore we refer to this paper for more details about the model development. The set of ERSEM model parameters, that have been calibrated in this study particularly for the Black Sea conditions, is shown in Table 1.

\section{MODEL RESULTS AND MODEL-DATA COM- PARISONS}

\subsection{Hydrodynamic Model Results}

In this section we present the results from the hydrodynamic Princeton Ocean Model (POM), modified to successfully simulate river plume dynamics. More details about the physical model set-up and its performance for the northwestern Black Sea are given in Kourafalou et al. (2004) and Tsiaras et al. (2008).

Two types of simulations have been completed for the transport and composition of Danube waters and associated nutrients on the Northwestern Black Sea shelf: (a) a multiyear climatological study to identify seasonal variability of the circulation and the typical transport pathways and nutrient uptakes; and (b) the target period $(2002$ - 2003) to reproduce observed patterns and validate the model against in-situ and satellite data.

The model simulations have utilized Danube River water and nutrient inputs taken from daily values on a longterm averaged record (1994 - 2001) for the climatological simulation and realistic daily values for the target period (Fig. 1a). The atmospheric inputs are of utmost importance on continental shelf dynamics and the coupled model includes all relevant air-sea interaction processes. The climatological simulations have utilized a perpetual year record 
of wind and air-sea fluxes where high frequency anomalies have been superimposed. The target period simulation has employed realistic, high-frequency (6-hourly) wind
(Fig. 1b) and flux readings obtained from the Poseidon operational atmospheric model (Papadopoilos et al. 2002; http://www.poseidon.ncmr.gr/).

Table 1. Values of selected biological parameters used in the numerical simulations (as in Vichi et al. 2003a, but for the current Black Sea set-up).

\begin{tabular}{lc}
\hline Parameter description & 0.7 \\
\hline Sediment porosity $(\phi,-)$ & 400 \\
Adsorption coefficient for phosphate in sediments $(-)$ & 0.5 \\
Characteristic time scale of DOM bacterial utilization $\left(v_{\mathrm{R} 1}, \mathrm{~d}^{-1}\right)$ & 0.1 \\
Characteristic time scale of detritus bacterial utilization $\left(v_{\mathrm{R} 6}, \mathrm{~d}^{-1}\right)$ & 1.0 \\
Characteristic time scale of phosphorus bacterial uptake $\left(v^{\mathrm{P}}, \mathrm{d}^{-1}\right)$ & 0.5 \\
Michaelis-Menten constant for phosphorus uptake by bacteria $\left(\mathrm{h}^{\mathrm{p}}, \mathrm{mmol} \mathrm{P} \mathrm{m}^{-3}\right)$ & 0.017 \\
Optimal N : C ratio in bacterioplankton $\left[\mathrm{n}^{\text {opt }}\right.$, mmol N $\left(\mathrm{mg} \mathrm{C}^{-1}\right]$ & 0.0019 \\
Optimal $\mathrm{P}:$ C ratio in bacterioplankton $\left[\mathrm{p}^{\mathrm{opt}}\right.$, mmol P $\left.(\mathrm{mg} \mathrm{C})^{-1}\right]$ & 25 \\
C: Chl-a ratio in diatoms $\mathrm{P}^{(1)}$ & 50 \\
C: Chl-a ratio in flagellates $\mathrm{P}^{(2)}$ & 50 \\
C: Chl-a ratio in picophytoplankton $\mathrm{P}^{(3)}$
\end{tabular}

(a) Danube Discharge rate $\left(\mathrm{m}^{3} \mathrm{~s}^{-1}\right)$

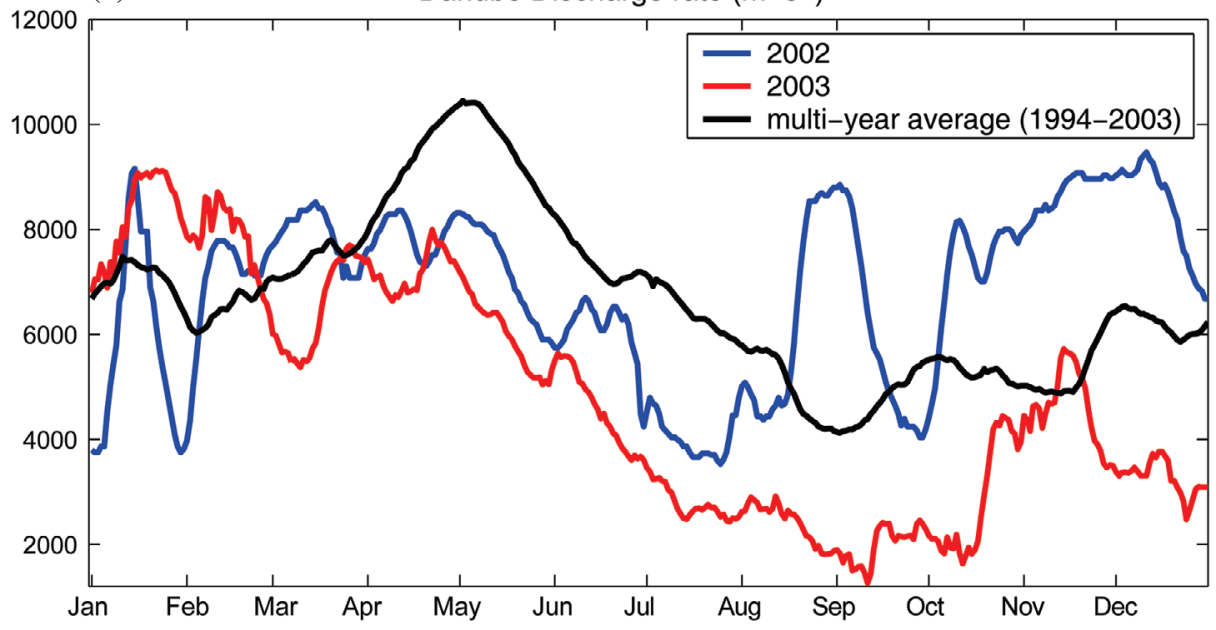

(b)

Wind Variability at point $\left(29.8^{\circ} \mathrm{E}, 45.1^{\circ} \mathrm{N}\right)$

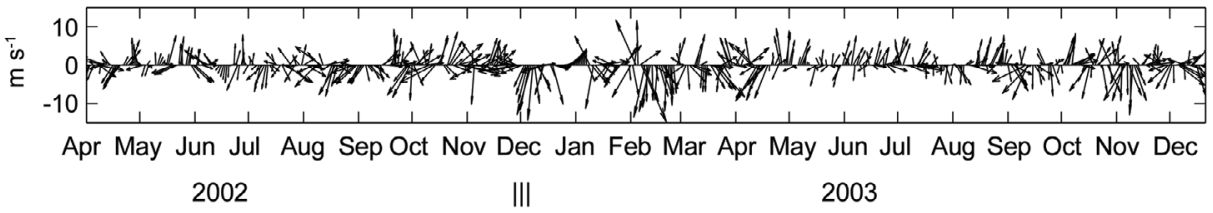

Fig. 1. Examples of model forcing. (a) The Danube discharge rate $\left(\mathrm{m}^{3} \mathrm{~s}^{-1}\right)$ for the years 2002 (blue line), 2003 (red line) and multi-year average (black line). (b) 6-hourly wind vectors from April 2002 to December 2003. 
Realistic model simulations (high frequency wind forcing and daily Danube water discharge) covered the target period 2002 - 2003. The target period was unique, as it covered two years with different conditions in both river and wind stress inputs. The differences are particularly evident in the two summer periods. Summer of 2002 had high discharge and downwelling-favorable winds, while summer 2003 had low discharge and upwelling-favorable winds. Examples of the summer season for the 2002 - 2003 model simulation and from 8-day satellite data composites for the same periods are shown in Figs. 2 and 3. The 6 - 10 September 2002 period (taken as late summer conditions) is the duration of the extended R/V Aegaeo survey that provided valuable data for model validation. The winds, averaged from 6-hourly values (source: HCMR operational "Poseidon" atmospheric model) are shown in Fig. 4. There is a remarkable agreement in the salinity patterns; it should be noted that the modelled salinity is a true average over the 5 cruise days, while the observed salinity is a close representation of the realistic pattern, since there is a time lag be-

\section{(a)}

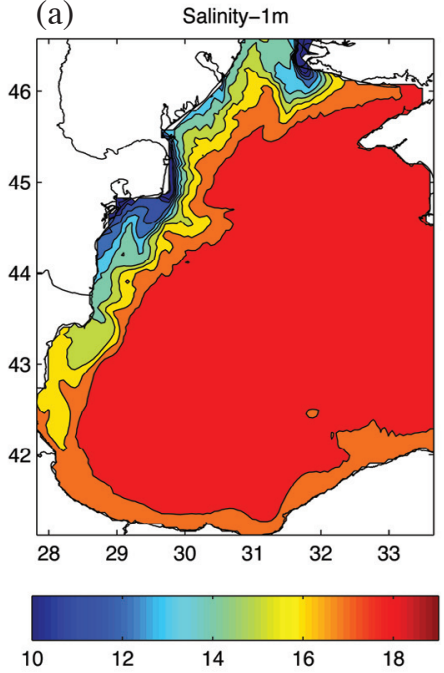

(b)

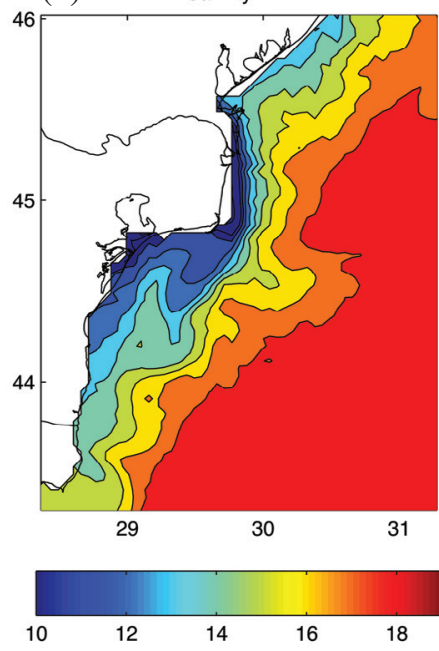

(c)

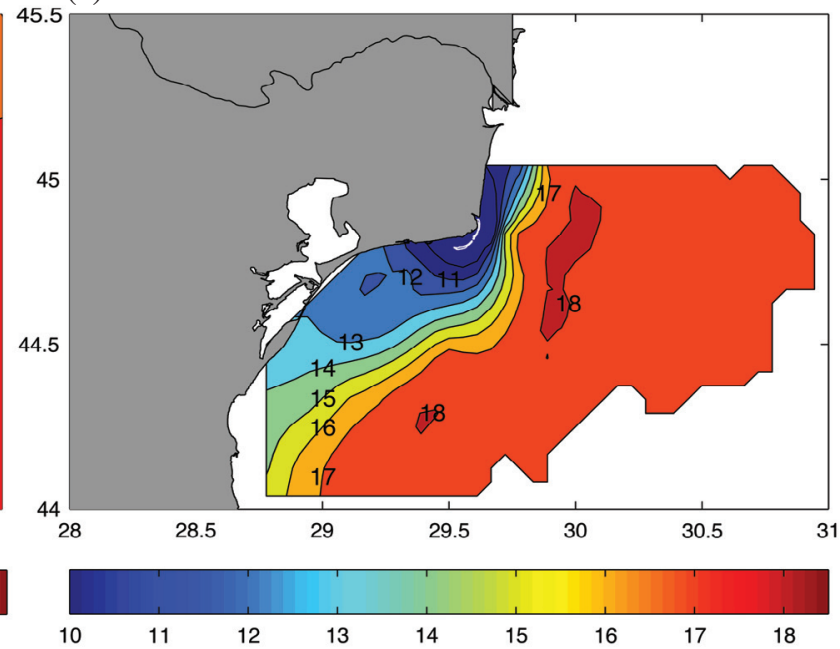

Fig. 2. Model to data comparison (averaged over the cruise period of 6 - 10 September 2002). (a) model surface salinity for the western Black Sea. (b) same, but zoomed in the data survey area. (c) the data survey surface salinity.

(a)
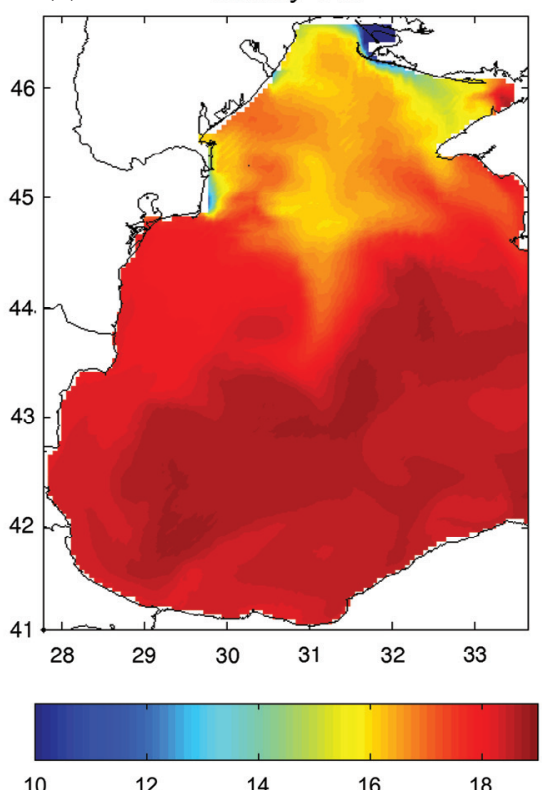

(b) Phytoplankton (mgr Chla $\left.\mathrm{m}^{-3}\right)-1 \mathrm{~m}$

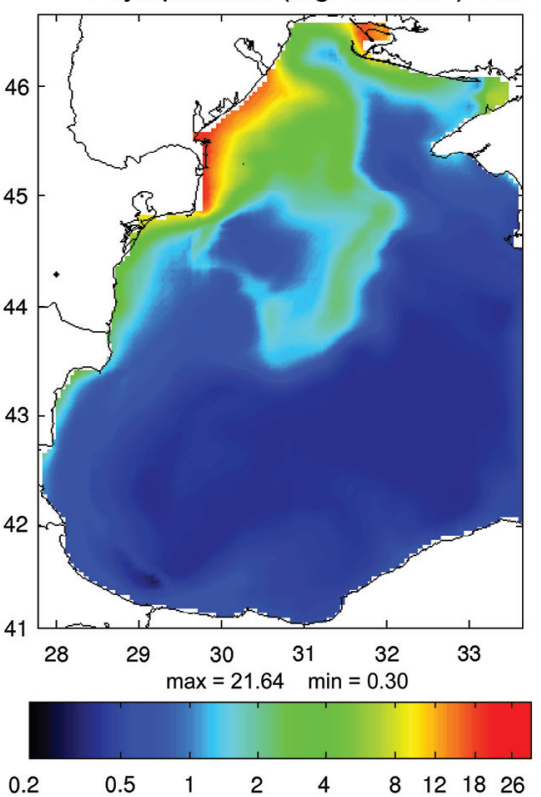

(c) SeaWiFS (mg Chla $\left.\mathrm{m}^{-3}\right)$

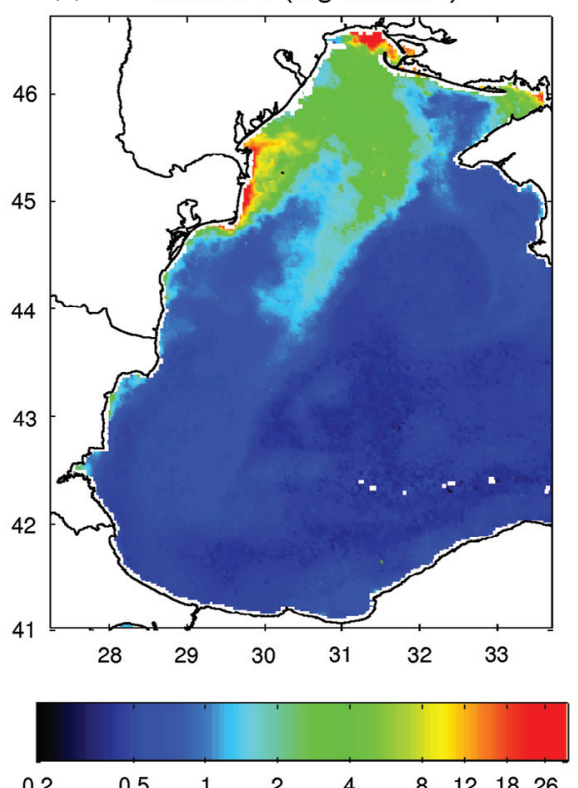

Fig. 3. Model to data comparison (averaged over 8 - 12 July 2003). (a) model surface salinity for the western Black Sea. (b) same, but for chlorophyll. (c) SeaWiFS chlorophyll. 

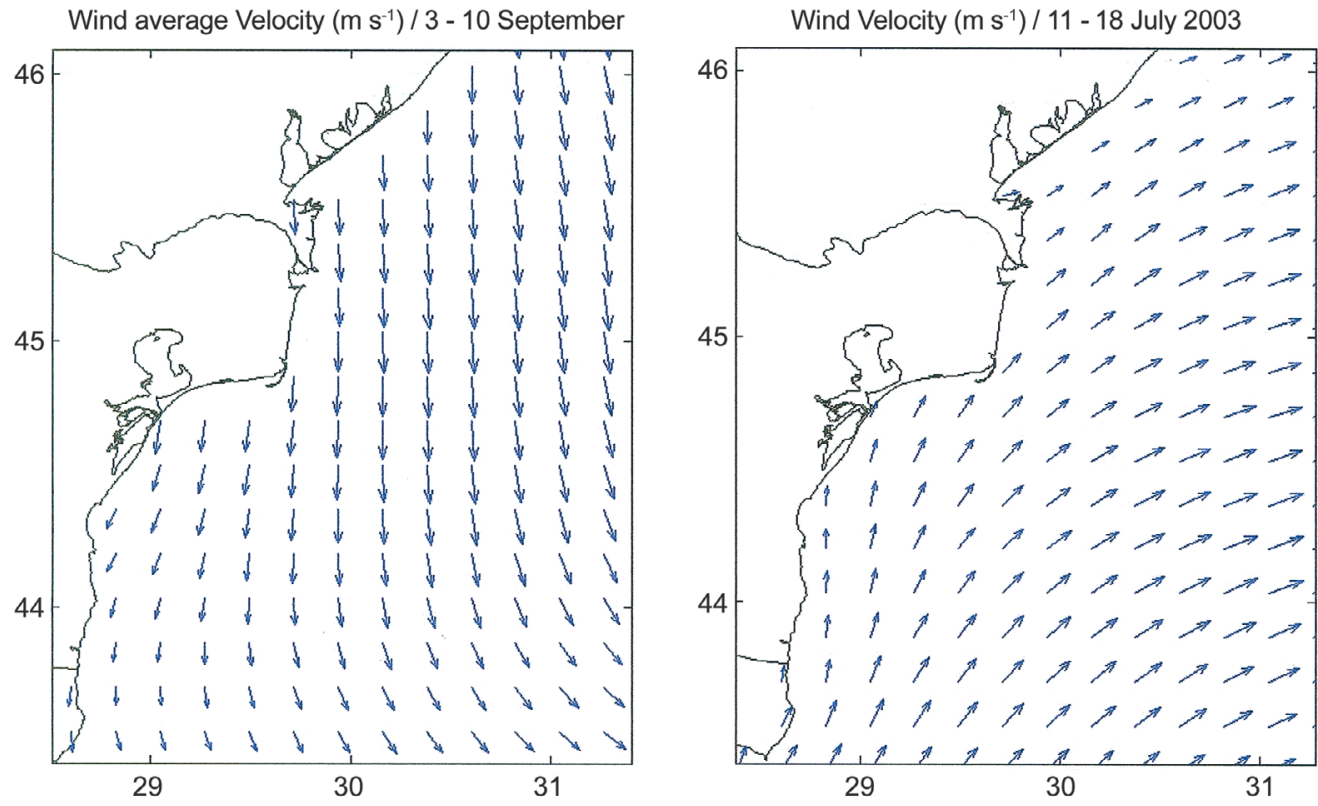

Fig. 4. Wind velocity averaged over the periods 3 - 10 September 2002 (northerlies) and 11 - 18 July 2003 (southwesterlies).

tween measured points. The Danube river plume variability is clearly illustrated in Fig. 5 where we show two horizontal patterns of the salinity and circulation for 15 May and 15 September 2002. In May 2002 the fresh water with Danube origin spreads offshore which is due to the favourable wind conditions, while on 15 September it stagnates along the western Black Sea coast.

\subsection{Mixed Layered Dynamics}

The performance of the mixed layer dynamics is illustrated in Fig. 6. It shows the time evolution of the depth of the upper mixed layer and of predicted sea surface temperature for the open Black Sea. The symbols displayed at each graph correspond to the data from observations (e.g., Staneva et al. 1997). It is clearly seen that there is quite good agreement between the data from the observations and the model results. The predicted thickness of the upper mixed layer fluctuates seasonally between 5 and $60 \mathrm{~m}$. The convective mixing is maximal at the end of February, displacing the Mixed Layer Depth (MLD) up to about $60 \mathrm{~m}$, reaching $6.5-7.0^{\circ} \mathrm{C}$. The permanent pycnocline maintained by the strong dilution of sea surface water (with salinity of about $18 \mathrm{psu}$ ) and the inflow of dense Mediterranean Sea water through the Bosphorus strait (with salinity of $35 \mathrm{psu}$ ) prevents deeper winter convection. The maximum temperature at the sea surface (about $24^{\circ} \mathrm{C}$ ) is observed during summer.

\subsection{Ecosystem Model Simulations}

Below we will discuss the results from the coupled physical-ecosystem model applied for 2002. We decided to concentrate our analyses on this particular year because of the large amount of observational data obtained there for the north-western Black Sea. The model area and the boxes where we make the comparisons are shown in Fig. 7. The location and size of the boxes were chosen according to the specific circulation characteristics of the north-western Black Sea (as detected by the three-dimensional hydrodynamic model and satellite observations, discussed in Tsiaras et al. (2008), but also according to the availability of the in-situ data during 2002 in Bulgarian and Romanian waters. Our primary motivation for performing detailed model to data comparisons was triggered by the desire to use as much observed data as possible. The model tuning has been done within the climatological type simulations utilizing all available in situ data. No additional tuning was performed for the 2002 simulations.

The total Danube River discharge into the sea during 2002 was $213.6 \mathrm{~km}^{3}$, slightly higher than in the previous two years due to above average precipitation over Europe. Monthly means ranged between $11.22 \mathrm{~km}^{3}$ in July and $22.52 \mathrm{~km}^{3}$ in November. In terms of the nutrient discharge, it is worth noticing the concentrations generally reflect a decreasing trend as recorded in previous years. This peculiarity is obvious for phosphates and nitrates, whose monthly means are lower than the long-term nutrient discharge. Conversely, silicates have recorded a slight increase both in spring and fall seasons, exceeding the long-term mean, in good agreement with the Danube discharge variations.

In this section we will analyse the response of the Romanian and Bulgarian coastal waters to the Danube nutrient discharge in 2002. The seasonal evolution of the temperature and salinity simulated by the coupled model (see Fig. 8) 

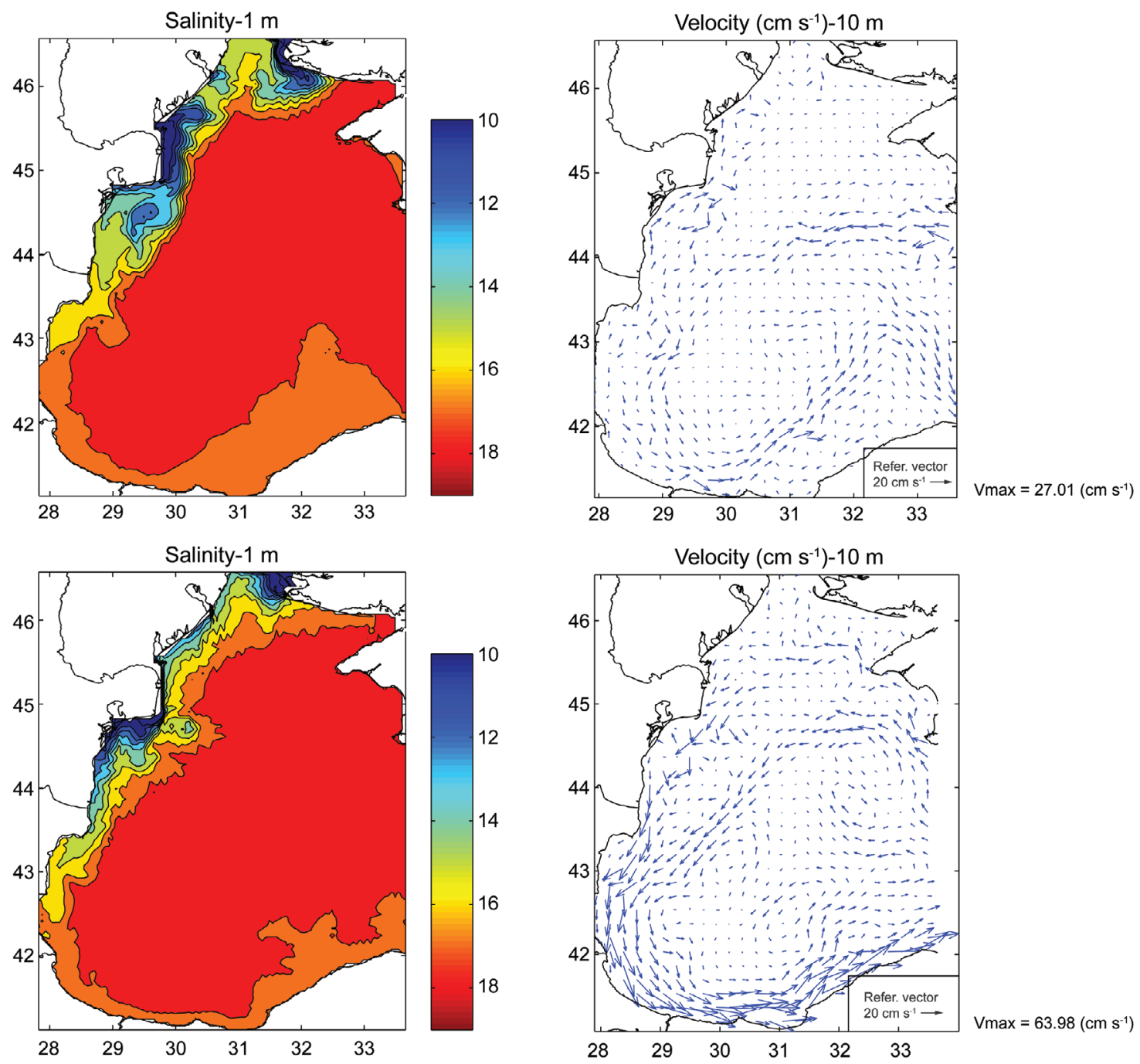

Fig. 5. Instantaneous horizontal distributions of salinity and velocity computed by the hydrodynamic model (POM) for 15 May 2002 (upper panels) and 15 September 2002 (bottom panels).
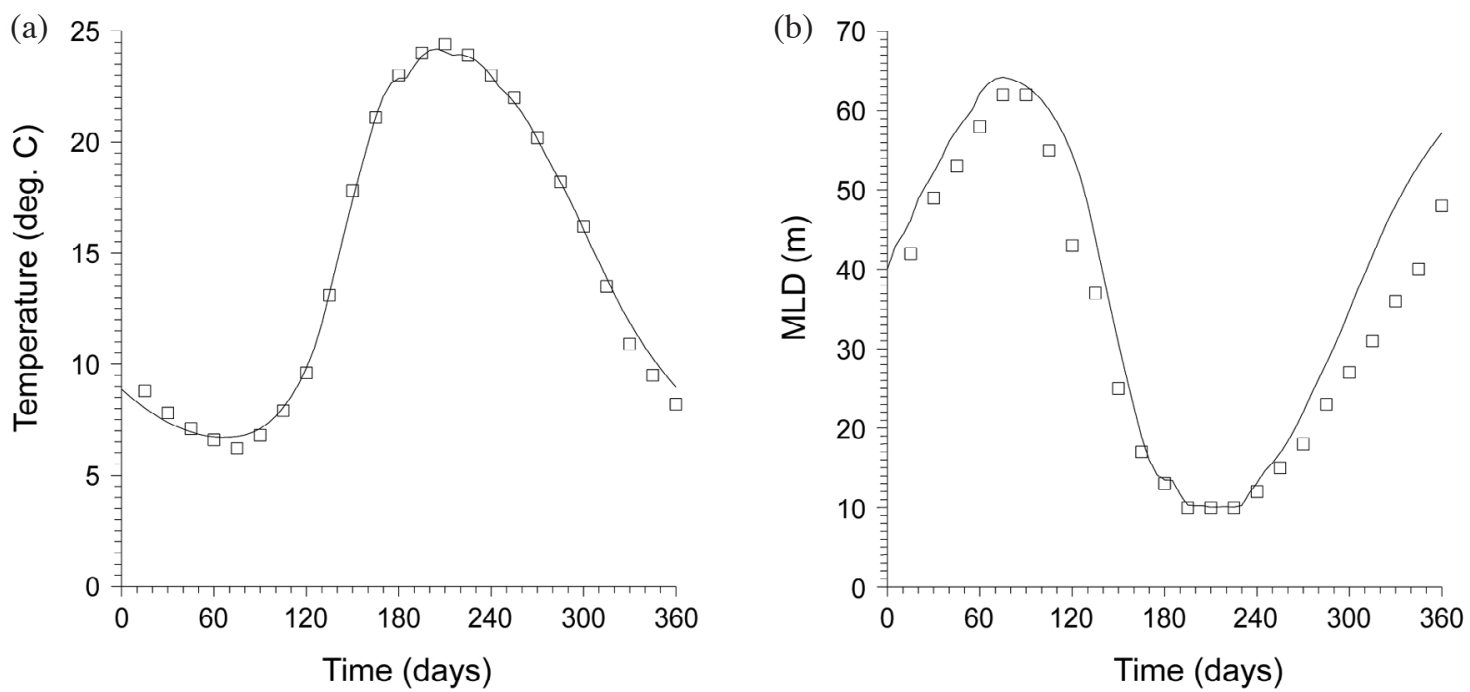

Fig. 6. Seasonal evolution of the (a) sea surface temperature and (b) mixed layer depth - MLD. Black line corresponds to model data, the symbols- to the observations. The units are given within the each pattern. 


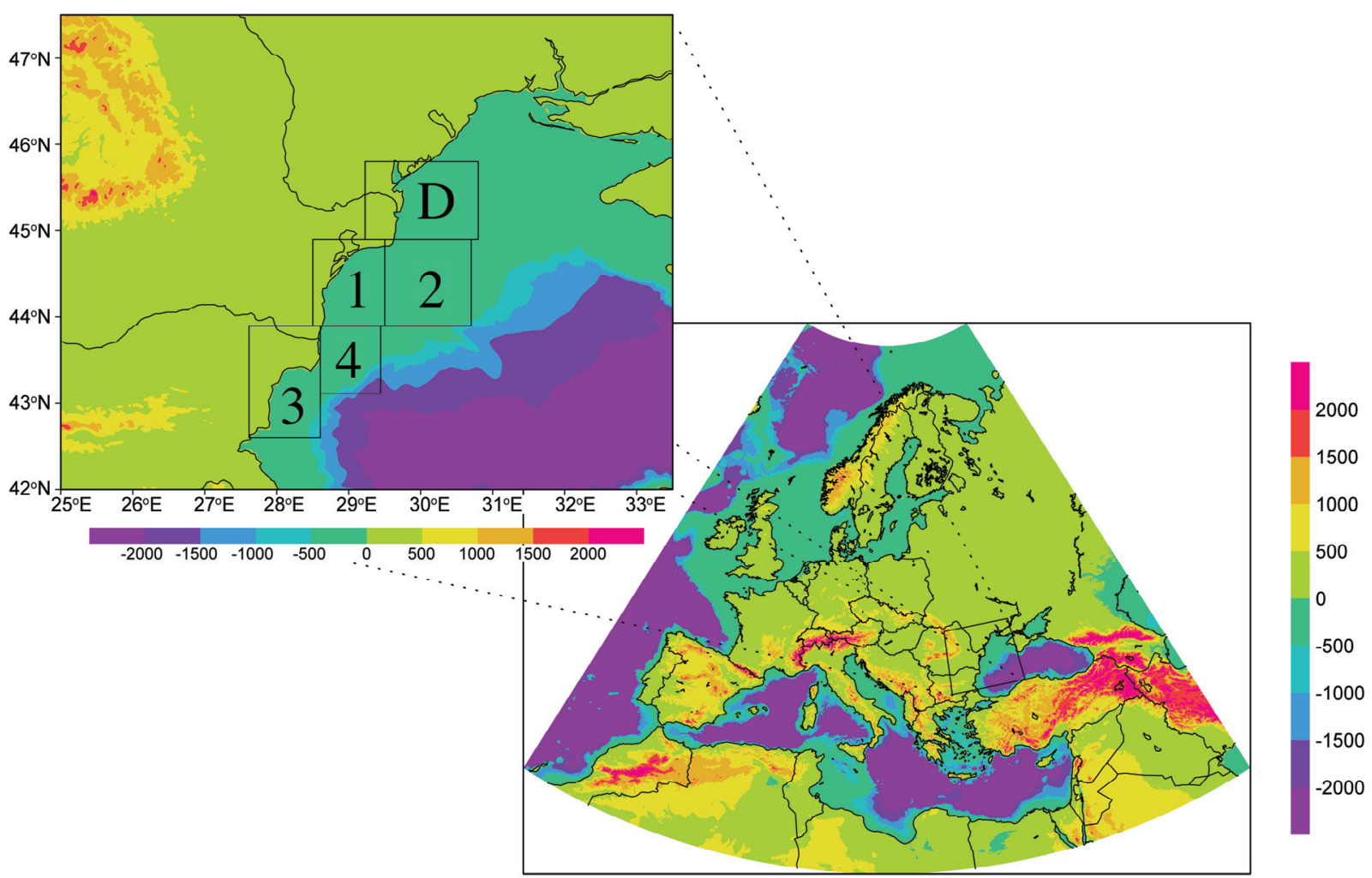

Fig. 7. Schematic representation of model boxes where model to data analyses have been performed.

(a) Temperature

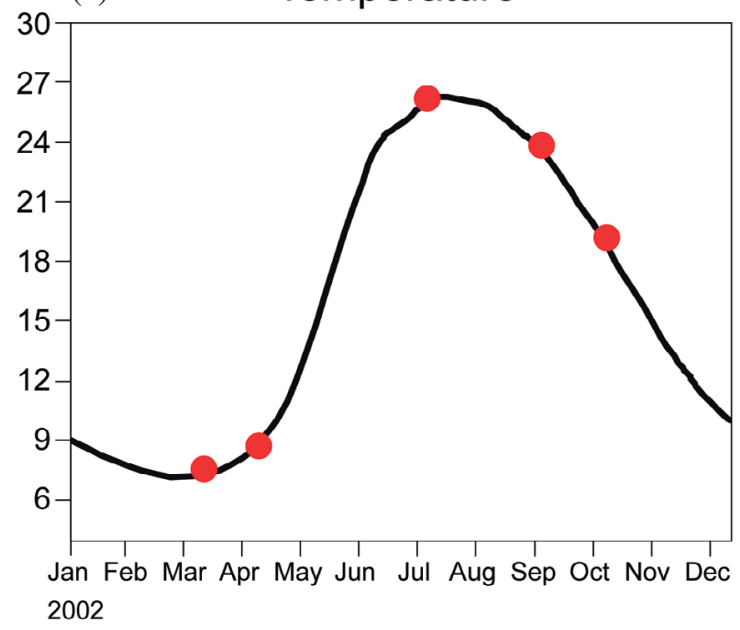

(b)

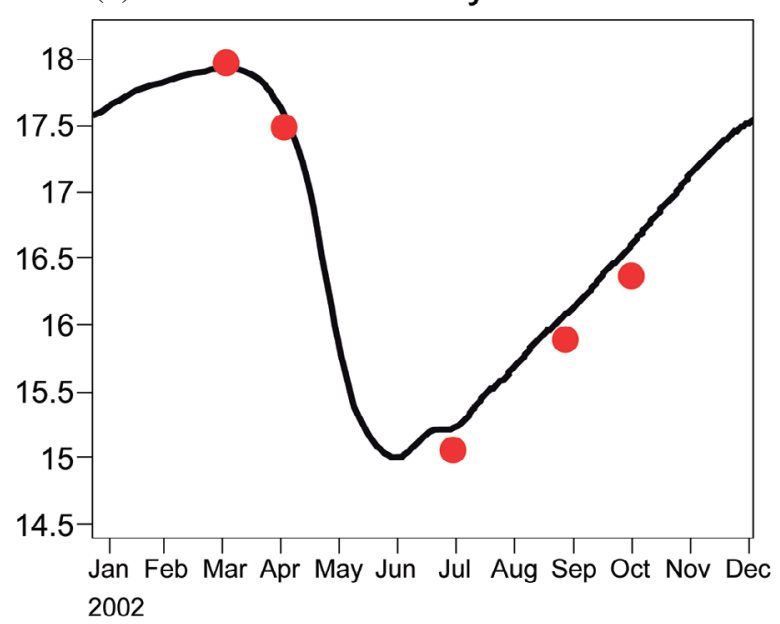

Fig. 8. Time evolution of: (a) temperature (deg. C) and (b) salinity (psu) during the simulations in 2002 (deg. C) for Box-2. Full line: model simulations, red symbols: data from observation, averaged for the corresponding box.

agrees very well with that observed in 2002 . The minimal temperature reached in mid March was about $3^{\circ} \mathrm{C}$ and the maximum in August was about $22.5^{\circ} \mathrm{C}$. Due to the joint effect of the precipitation and high freshwater input from the Danube the minimum salinity was observed in the summer.

The mean vertical profiles of phosphates, nitrates and silicates are shown on Fig. 9. The black profile corresponds to model simulations and the red one to observations. One sigma deviation from the mean of model simulations is given as well. A proper representation of the vertical structure of nutrients is very important in order to simulate a correct seasonal cycle of the biogeochemical variables of the northwest Black Sea. As seen from Fig. 9 the model fits very well with the observations. The highest variability for the 
nitrates (Fig. 9c) is simulated in the uppermost layer while for silicate and phosphates the whole column maintains a high temporal and space variability. The vertical profiles of silicates (Fig. 9b) are very homogenous. The nitrates and phosphates concentrations increase from the sea surface to the bottom with the strongest vertical gradients between 30 and $50 \mathrm{~m}$.

Below we will analyse the time evolution of key biogeochemical variables during the simulations in 2002 together with the related time series of the observational data, whenever available. The in-situ data have been averaged within the model boxes for a more realistic comparison and the one-sigma (standard) deviations from the mean have also been plotted. The data used for validations are taken from the observations in 2002 provided from the DANUBS project observations (see http://danubs.tuwien.ac.at and also Velikova et al. 2005).

In 2002 in coastal waters, phosphates (Fig. 10a) were decreased below the long-term average, similar to the Danube phosphorus discharge. The phosphorus concentration in all regions was kept below $0.5 \mathrm{mmol} \mathrm{m}^{-3}$ during April to December 2002. In the annual cycle, a remarkable decrease was predicted in summer, due to the intensive biological activity and lower river discharge. The model predictions are in very good agreement with observations. The mean phosphorus diagnosed by the model is slightly underestimated in comparison with the mean data, but lies within one sigma error from their mean values. The most important result here is that model predictions confirmed that the phosphorus is assumed to be the major limiting factor during 2002. Silicates (Fig. 10c) leaching into the north-western Black Sea coastal areas was predicted with higher values at the beginning of 2002. The concentrations of silicate through 2002 vary in a large spectrum, between 4 and $33 \mathrm{mmol} \mathrm{m}^{-3}$. A decrease of silicate was observed starting from May to September. Again the model is able to simulate both a correct seasonal cycle and mean concentrations in good agreement with the data from observations. Ammonia (Fig. 10d) does not play a significant role in 2002. The seasonal variations of ammonia are rather small compared to the other nutrients.

Monthly means of the nitrates concentration predicted by the model (Fig. 10b) are similar to the values recorded during the 1990 - 2000 period (not shown here). This corresponds to the observational evidence. Two maxima were observed in April and October. The time of those maximum values shifted slightly in south and off-shore directions. The minimum of nitrates concentrations is observed in July in all regions.

The N/P and Si/P ratios (Figs. 11a, b), calculated for the Romanian and Bulgarian coastal waters throughout year 2002, are higher than in the mean situation over the past 15 years, due to the continuous decrease of phosphorus, compared to nitrogen and silica. On the other hand, $\mathrm{Si} / \mathrm{N}$ ratio is close to the mean values due to the variations in both nutri- ents. Regarding oxygen, the model prediction in all boxes demonstrated that the water has been properly oxygenated during the entire year, with no hypoxia phenomena and no excessive over saturation of the superficial layer.

How did phyto- and zooplankton respond to nutrient discharge in 2002 ? As seen from the model simulations, the net numerical majority of the 2002 year phytoplankton was represented by the diatoms (compare Figs. 12a and b). This statement is again in a very good agreement with the data from measurements (Velikova et al. 2005). The extension of the phosphate concentration diminishing process explains the reduction of the total phytoplankton quantities in 2002.

The extreme decrease of the numerical abundance incurred especially to the flagellates (Fig. 12b) (main bloom producers in the years 1980 and 1970), paralleled by maintaining the diatoms (Fig. 12a) as a net prevailing numeric group, can be partially explained by the enhanced increase of the $\mathrm{Si}$ : $\mathrm{P}$ ratio in the coastal waters. The process of the decrease of the magnitude and frequency of the blooms, as well as the maintenance of the prevalent weight of the diatoms, are signals of positive evolution of the planktonic algoflora toward its natural pattern. This contradicts the mean situation during the "eutrophication" period (1970's and 1980 's) proving a recovery of the Black Sea ecosystem in the recent years. Therefore, it could be also concluded that the importance of dinoflagellates is substantial throughout the yearly cycle almost at the level of the diatoms.

In spring, the copepods concentration is relatively low (Fig. 12c). After that, in summer 2002, the model predicts a substantial accumulation in all the feeder groups compared to the spring (the maximum concentrations in summer vary between 14 and $22 \mathrm{mg} \mathrm{m}^{-3}$ ). The quantities depleted towards the autumn (with values between $3-10 \mathrm{mg} \mathrm{m}^{-3}$ ). The results obtained in 2002, when no ample bloom is observed in the phytoplankton evolution, emphasised an improvement of the structure of zoobenthic communities. The seasonal distribution of bacteria in coastal waters of the Black Sea in 2002 (Fig. 12d) seemed to be interrelated in many instances, but this was not always the case with the main biotic and abiotic factors: temperature, organic substance, total phytoplankton. In the north-western Black Sea, an increase in bacterial density and biomass was found in 2002 in comparison with the mean situation in the last two decades.

\section{SENSITIVITY OF THE ECOLOGICAL MODEL TO CHANGING OF NUTRIENT DISCHARGE}

The model simulations displayed below employ climatological monthly mean forcing for the 80's and 90's and demonstrate the sensitivity of the coupled model to long term changes in the Danube nutrient loads. We will compare the seasonal cycle of nutrients and biological variables in the Danube plume area (herein defined as the area with salinity lower than $17 \mathrm{psu}$ ), predicted by the model for two periods, 
characterised by different nutrient loads. The periods were chosen as three-year averages in 1980 - 1983 and 1990 1993, respectively. All comparisons and model analyses are performed within the mixed layer. A significant interannual and seasonal variability of Danube nutrient concentrations is observed during the simulated periods (Fig. 13, upper pat- terns). These fluctuations are due to human-induced changes in the Danube watershed and/or different biogeochemical transformations in the river, which had dramatic consequences for nutrients concentrations at the Danube outflow in the Black Sea. Phosphate is the most changing nutrient, with increasing concentrations and peaking in $1990-1993$ (a)

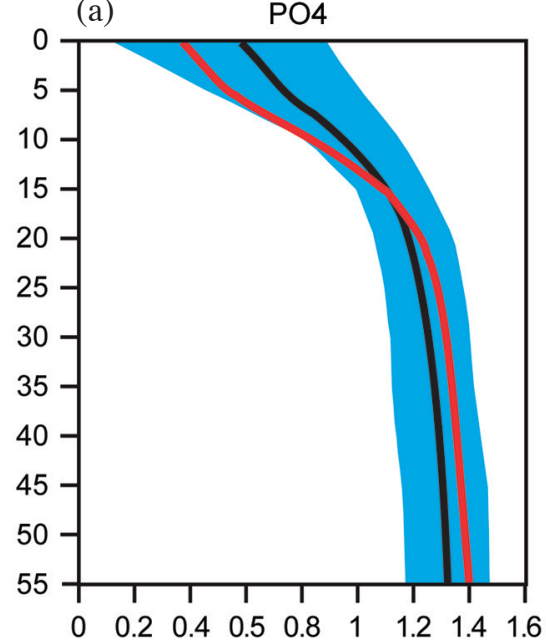

(b)

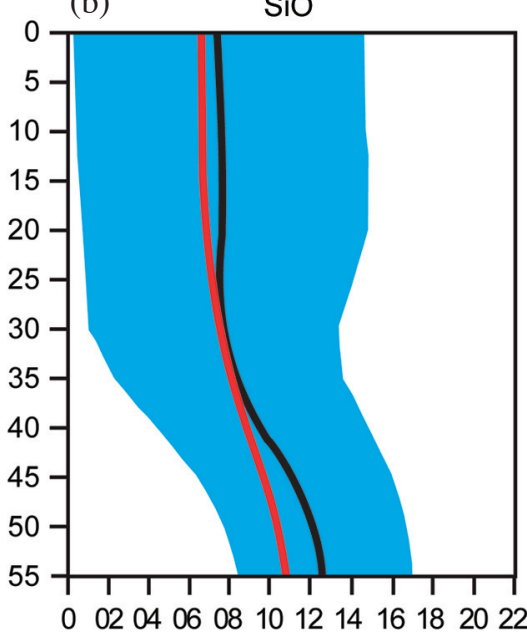

(c)

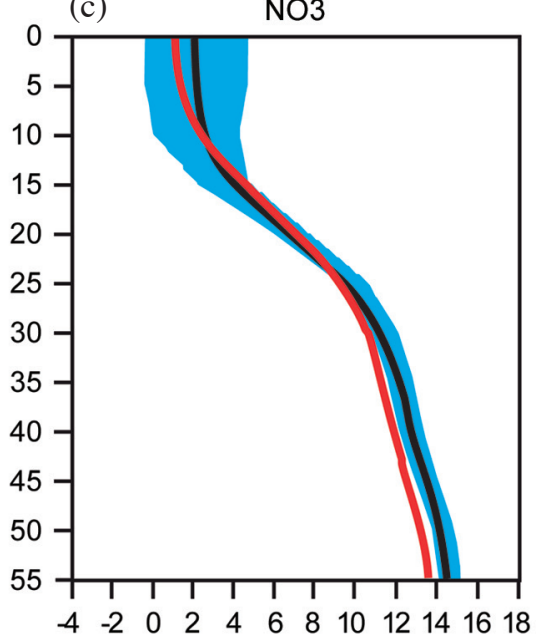

Fig. 9. Vertical profiles of: (a) PO4, (b) SiO, and (c) NO3 for the north-western Black Sea in 2002. Red line: observations, black line: model simulation, blue shading: 1- $\sigma$ deviation from the mean model data.

(a)

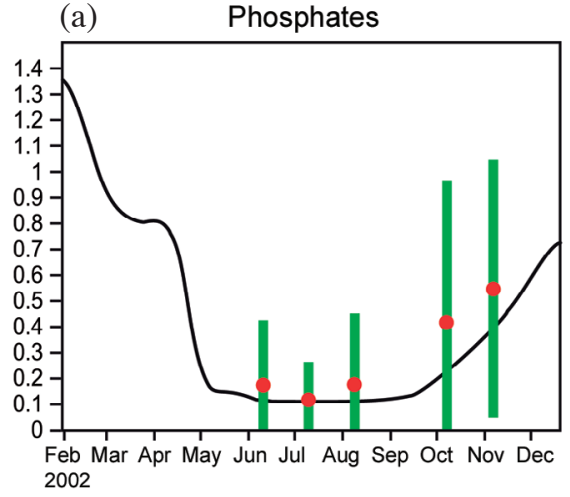

(d)

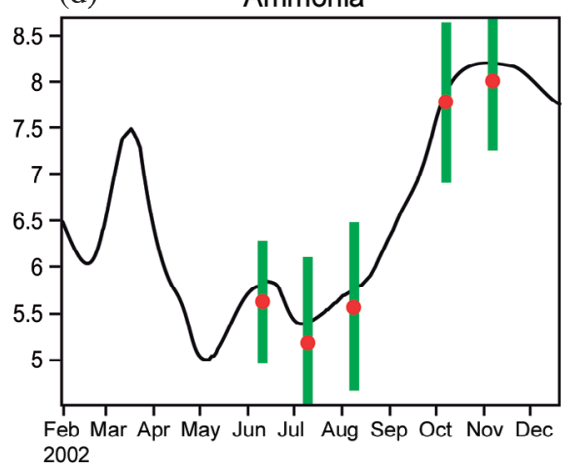

(b)

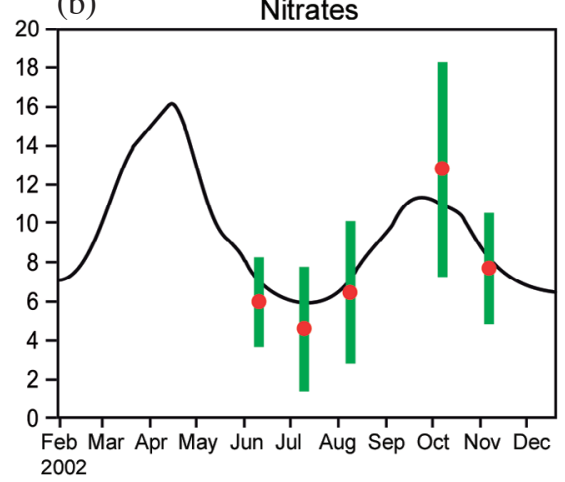

(e)

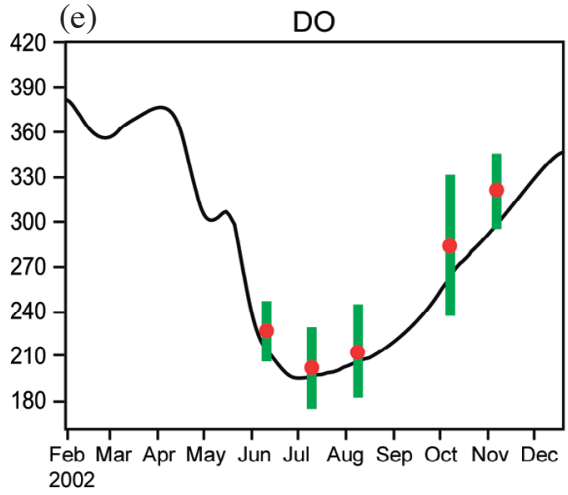

(c)

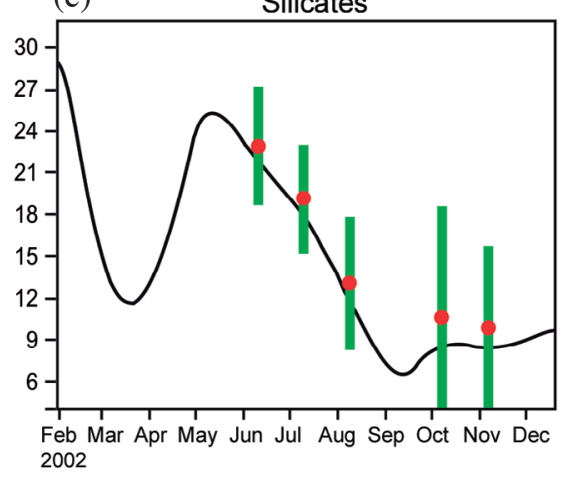

Fig. 10. Time evolution of: (a) phosphate, (b) nitrates, (c) silicates, (d) ammonia, and (e) dissolved oxygen during the simulations in 2002 $\left(\mathrm{mmol} \mathrm{m} \mathrm{m}^{-3}\right)$ for Box-2. Full line: model simulations, red symbols: data from observation, averaged for the corresponding box, green lines: 1- $\sigma$ deviation from the mean data from observations. 

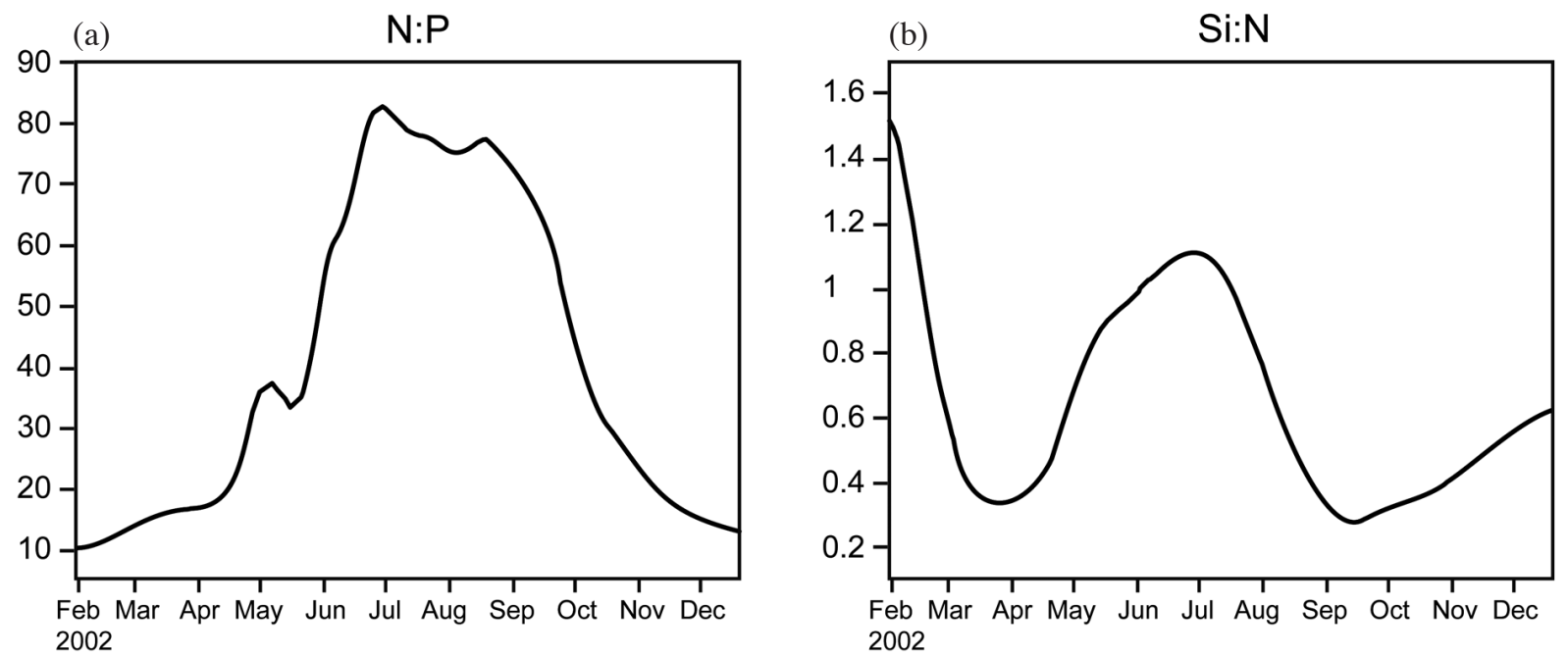

Fig. 11. Time evolution of: (a) N : P, (b) Si : N ratio during the simulations in 2002 for Box-2.

(a)
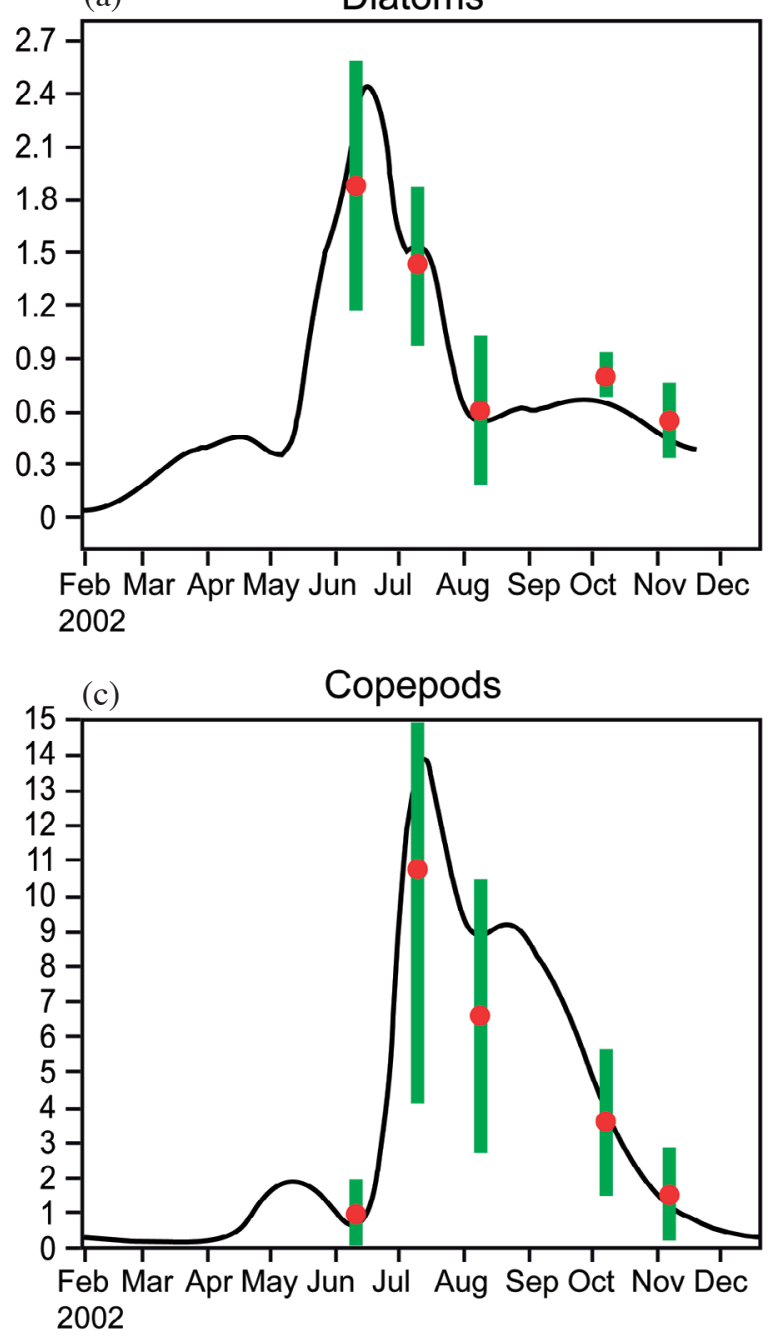

(b)

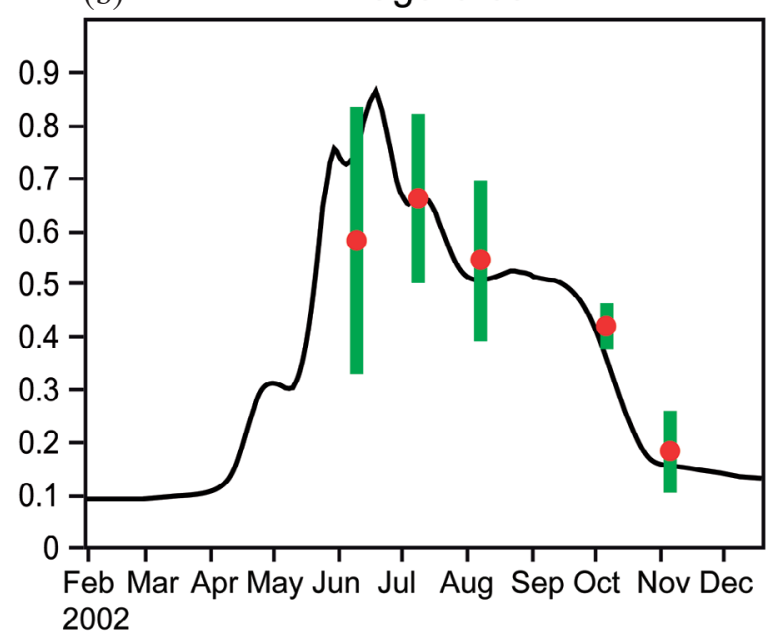

(d)

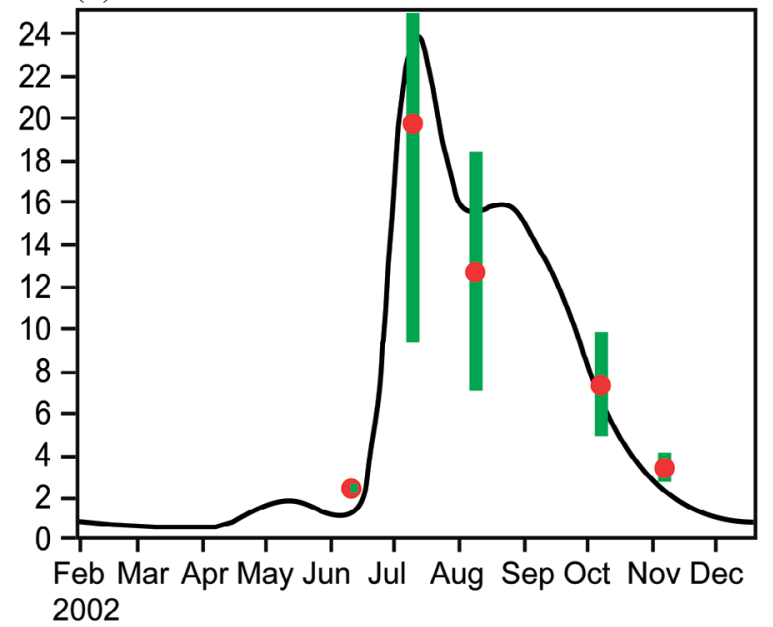

Fig. 12. Time evolution of : (a) diatoms (mg. Chl/a. $\mathrm{m}^{-3}$ ), (b) flagellates (mg. Chl/a. $\mathrm{m}^{-3}$ ), (c) copepods (mg. C. $\left.\mathrm{m}^{-3}\right)$, (d) bacteria (mg. C. $\left.\mathrm{m}^{-3}\right)$ during the simulations in 2002 for Box-2. Full line: model simulations, red symbols: data from observation, averaged for the corresponding box, green lines: $1-\sigma$ deviation from the mean data from observations. 


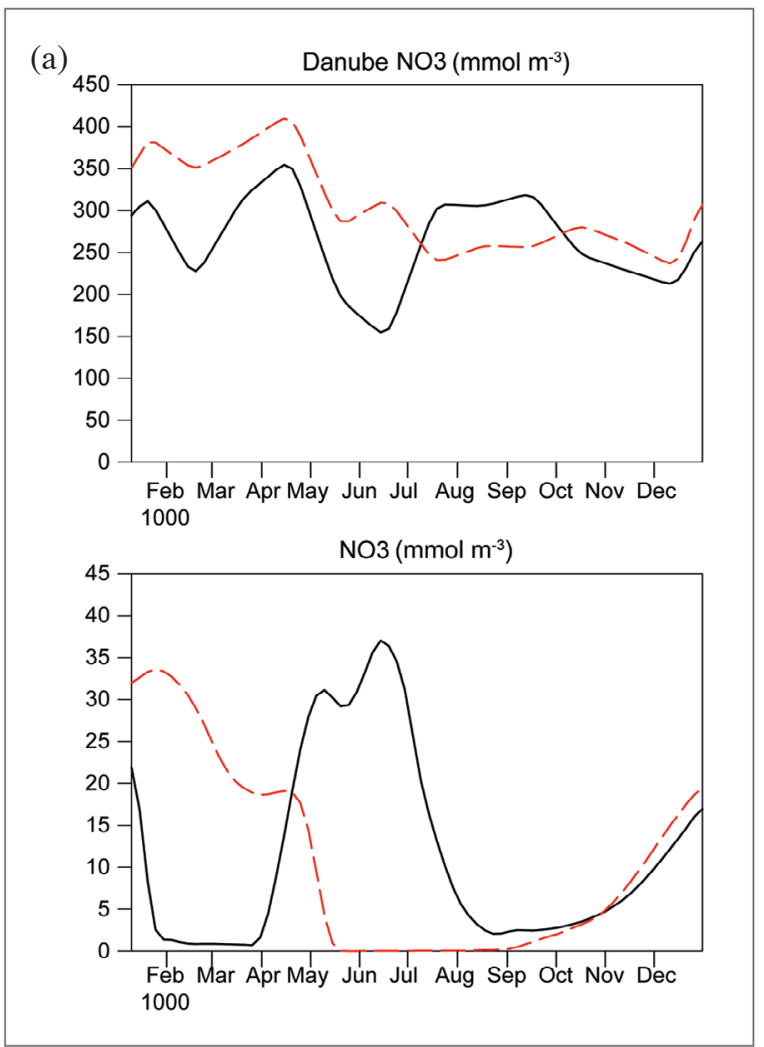

(b)
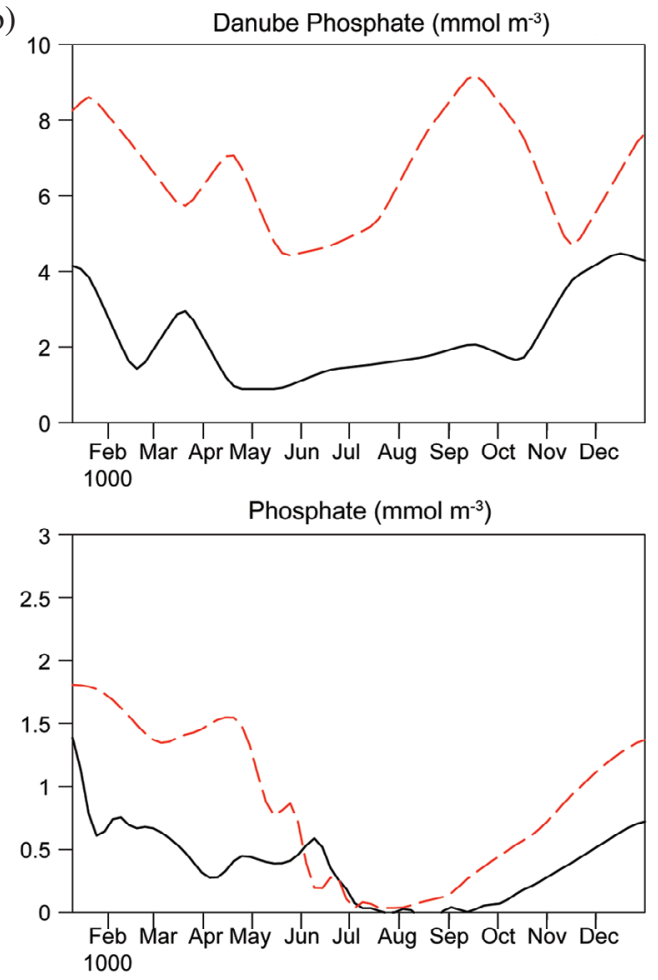

Fig. 13. Time evolution for (a) nitrates and (b) phosphates: (top) Danube discharge; (bottom) simulated by the three dimensional coupled model and averaged for the whole north-western Black Sea. Full line corresponds to the period 1980 - 1983, the dashed line corresponds to the period 1990 - 1993.

while silicates concentrations are reduced in this period. Winter concentrations of nitrates and phosphates, predicted by the coupled model in the Danube plume area (see Fig. 13, lower patterns) are mainly due to the imposed changes of the nutrient loads, based on measurements (A. Cociasu, personal communication). The simulated winter stocks of nutrients in the plume area in the early 90's are quantitatively higher compared to that of 1980 - 1983.

The predicted seasonal cycle of nutrients in the Danube-Black Sea mixing zone also reveals seasonal fluctuations with expected lowest values in the spring-summer period due to biological activity. However, the strong time lag of the nutrient spring decrease suggests a different response of the phytoplankton community and related heterotrophs (Figs. 14 - 16). The seasonal evolution of the biological variables is predicted by the model response to the Danube-driven nutrient inputs. In the nutrient-rich conditions the concentration of Chlorophyl-a is more than two times higher than what is observed in the early 80's (see Fig. 14). The model stimulates the spring bloom of diatoms and flagellates about one-month earlier in the 90's in comparison to the 80's (compare dashed and full lines at Fig. 14). These nutrient-rich conditions stimulate high biomass of the mesozooplankton, as well. On the contrary, the model predicts insignificant development of the microbial network composed of bacteria and microzooplankton (Figs. 15 and 16). What is clearly seen from the model simulations is that not only the concentrations were changed, but the seasonal cycle as well. The spring maximum of the primary production, averaged within the mixed layer depth is predicted in March for the period 1980 - 1983, while for 1990 - 1993 it is in February and a second spring maximum is observed in May. The model results described here indicate that the biological system is very sensitive to the changes in both nutrient concentrations and to $\mathrm{C}: \mathrm{N}: \mathrm{P}: \mathrm{Si}$ ratios. These results as well as the missing "spring bloom" (presented for the period 1990 - 1993 in Fig. 14) which is very well described by the model results, reflect the key alterations typical for the phytoplankton assembly in the period after 2000 at basin-wide scale (see Nesterova et al. 2008 and the references there in).

\section{DISCUSSION}

\subsection{Model Physics}

The hydrodynamic model results elucidated the processes that influence the transport and fate of Danube waters. These processes are fundamental for the transport rates 

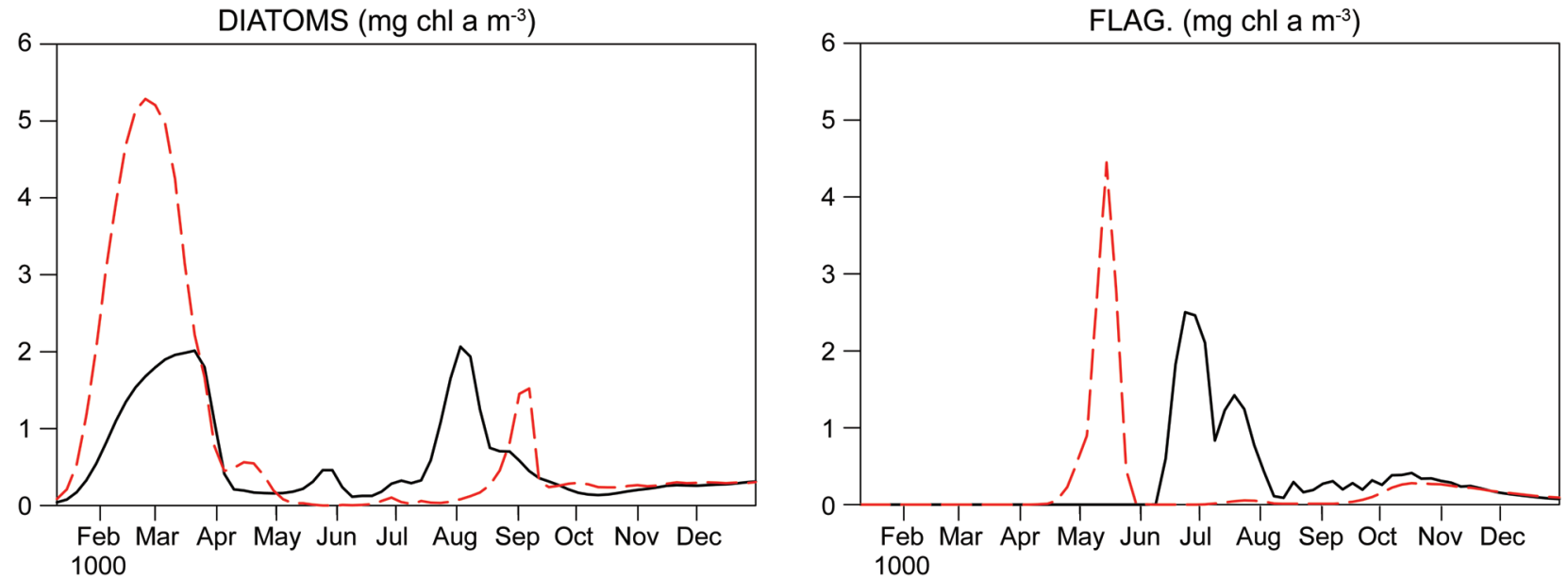

Fig. 14. Time evolution of diatoms and flagellates, averaged within the mixed layer depth. Full line corresponds to the period $1980-1983$, the dashed line corresponds to the period 1990 - 1993. The units are given on the top of each pattern.
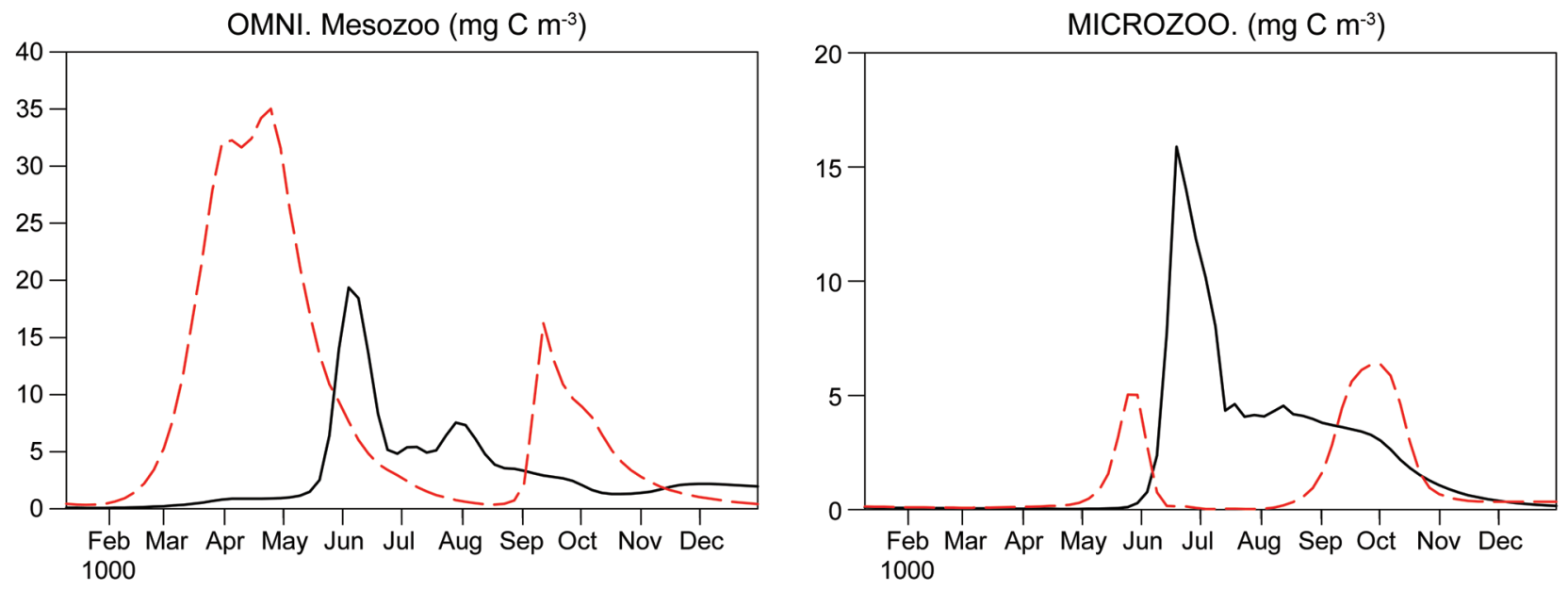

Fig. 15. Time evolution of some of meso- and micro- zooplankton, averaged within the mixed layer depth. Full line corresponds to the period 1980 - 1983, the dashed line corresponds to the period 1990 - 1993. The units are given on the top of each pattern.
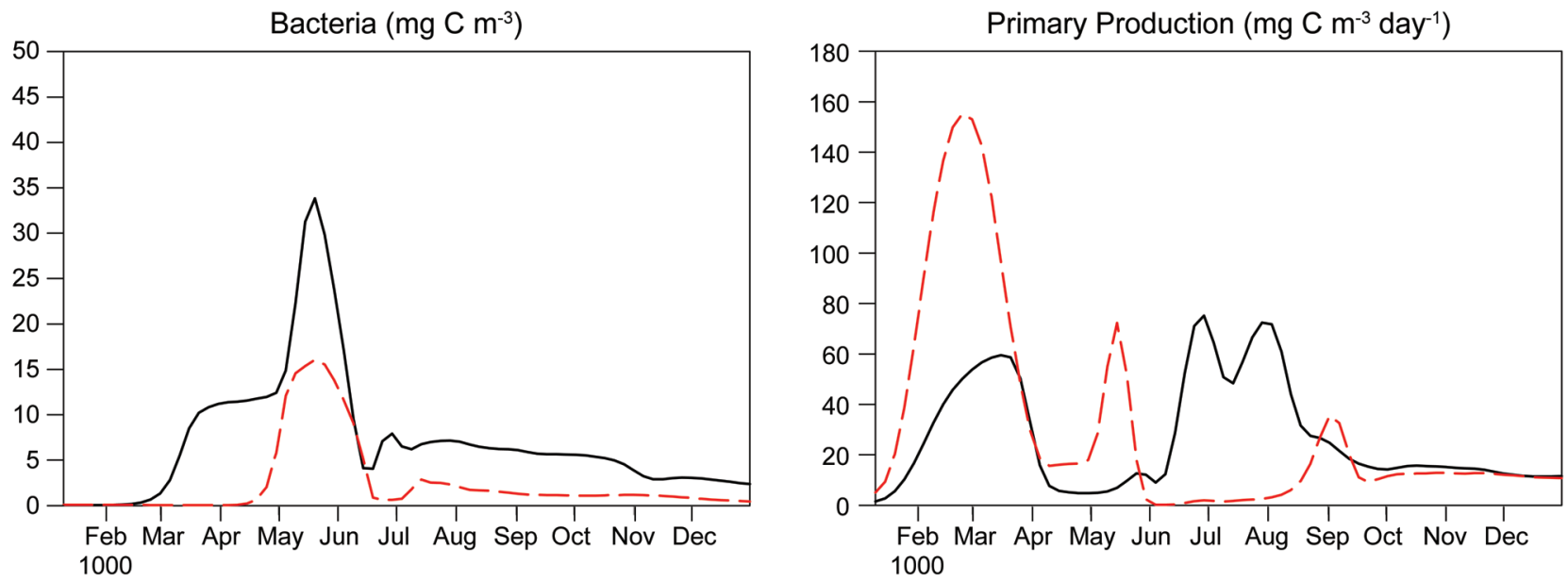

Fig. 16. Time evolution of bacteria and the primary production, averaged within the mixed layer depth. Full line corresponds to the period 1980 1983, the dashed line corresponds to the period 1990 - 1993. The units are given on the top of each pattern. 
and pathways of the low salinity waters that originate in the Danube delta. The nutrient pathways are largely influenced by the hydrodynamic processes, while subject to biological processes that are included in the ecosystem modules. The most important circulation forcing mechanisms that influence transport in the western Black Sea shelf are: (a) buoyancy, due to the river discharge (primarily the Danube, but also from remote inputs from the rivers Dniestr, Dniepr and Bug); (b) air-sea interaction: changes due to wind, heat (solar radiation) and salt fluxes (evaporation, precipitation); (c) topographic controls, delta shape, bottom friction, innershelf slope; and (d) interaction with the basin-wide circulation and in particular the Rim Current .

The climatological model simulations concentrated on seasonal variability and allowed model validation with data averaged distributions that were derived from long term observations. The main finding was that the amount of Danube river discharge and the direction and magnitude of the wind stress were the main factors that determined the formation and evolution of the Danube River plume and therefore the transport pathways of the Danube inputs. The plume was further modified by topographic features around the delta. In general, during winter (December - February) the water column is well-mixed and the prevailing winds are strong and mostly downwelling favorable (from the North, Northeast) in the Danube area. The Danube plume is deepened and constrained near the coast and directed to the south. During summer, winds are much weaker, the water column is stratified and occasional southern winds enable the offshore advection of the low-salinity waters toward the East, Northeast.

The influence of wind is particularly evident in the model computed surface salinity and nutrient distributions as well as on satellite measured chlorophyll. Northerly and easterly winds (downwelling favorable ) press the low-salinity, eutrophic surface waters towards the coast, in an elongated, narrow band. The river influenced area is deepened vertically. The opposite takes place with southerlies and westerlies (upwelling favorable) winds: offshore advection of riverine waters, expansion of the plume width, reduction of the southward transport and of the vertical width of the plume layers. In cases of strong discharge, the effect of the wind is substantially weakened. Westerly winds can drift surface water, influenced by the Danube River far towards the central western Black Sea. A special case is strong southern wind or moderate to strong south-western wind, preventing the southward spreading of Danube waters, generating offshore oriented surface currents with the consequence of vertical water transport towards the sea surface waters, frequently from bottom layers, with low temperature and high salinity (upwelling). This phenomenon often takes place in early summer, when the thermocline is not well established and the requested energy can be provided by wind. Then in several hours the water temperature can decrease by up to $10^{\circ} \mathrm{C}$ and salinity increase up to $19.0 \mathrm{psu}$, as is often observed in June in the Western Black Sea coastal areas The upwelling events in the Western part of the Black Sea are usually of local character, rather small in scale, spatially up to 20 - 30 miles off the coast and temporarily a few days depending on the duration of the westerly winds.

\subsection{Biogeochemical Results}

The regional Seas Ecosystem Model (ERSEM) has been applied for the first time for biogeochemical simulations of the Black Sea ecosystem. The model is coupled to a hydrodynamic model and a mixed layer model. It is forced with fluxes, obtained from realistic meteorological conditions. The main advantage of the model set-up for the Black Sea conditions is the possibility to study: (i) the capacity of the Black Sea for primary production; (ii) the evolution of the chemical structure under changing boundary conditions. The model results described here indicate that the biological system is very sensitive to the changes in both nutrient concentrations and to $\mathrm{C}: \mathrm{N}: \mathrm{P}: \mathrm{Si}$ ratios.

A comparison between the weekly mean chlorophyll-a distributions simulated by the coupled model (top patterns) and from and SeaWiFS satellite images (bottom patterns) is demonstrated in Fig. 17. The coupled model was able to capture basic physical and biological processes affecting phytoplankton variability and presented a good agreement with SeaWiFS images. Weekly composites of chlorophyll-a distributions were computed from daily SeaWiFS images provided from A. Davidov (via personal communications). Areas near the Danube plume and along the western Black sea coast and shelf are characterised by relatively high production throughout the year due to the continuous supply of nutrients by river discharge (primarily by Danube and also by Dnepr, Dnestr, Bug) and additionally due to the increased stratification caused by the low salinity zone. Highest values are observed in the Danube plume area, which sometimes extends to the east or is confined to the coast depending on the wind conditions. High values are also observed in the areas surrounding the other Northwestern shelf rivers and also in the bay North of the Crimean peninsula. This latter area is a closed very shallow area $(\mathrm{H} \sim 10 \mathrm{~m})$ where probably accumulation of biogenic material is providing a source for continuous re-suspension of nutrients. The Danube influenced area is clearly identified in the SeaWiFS Chl-a images and the model simulated Phytoplankton especially during summer when nutrient limitation is stronger and Danube provides the main nutrient supply. During the summer (June - August) of 2003 prevailing winds are mostly southerlies causing the advection of the Danube plume to the NorthEast, while in September 2003 and September 2002 winds are northerlies advecting the plume to the south stagnating to the western Black Sea coasts. The comparisons between the model and the satellite images demonstrate that the cou- 
pled model works reasonably well with respect to simulating correct phytoplankton dynamics. The snapshots of the horizontal patterns of nitrates and phosphates (see Figs. 18 and 19) also reveal the strong variability of the Danube plume in connection with a complexity of factors like the atmospheric forcing, nutrient discharge from the rivers and internal ecosystem dynamics.

Model simulations with realistic forcing for 2002 show that the coupled physical and biological models, that have been developed and tuned for the Black Sea ecosystem and in particular for the ecosystem in the vicinity of the Danube River plume, produce data validated distributions of the hydrodynamic and biological parameters that are directly connected to the marine impact of freshwater and nutrients released in the Danube. A hierarchy of models has been described, based on food-chain structure and physiological concepts reaching a full ecosystem representation. It was shown that the hydrodynamic and low trophic coupled model gave a realistic representation of the development and evolution of the river plume structure and the nutrient distribution within the plume, under conditions of varying water and nutrient inputs and under the influence of rapidly changing meteorological conditions. The good comparison with observations suggests that the full ecosystem model has the required trophic resolution to address the ecological changes into the Black Sea. The numerical results indicate that coastal eutrophication-related problems are not only driven by the quantity of nutrients discharged into the coastal system, but are also greatly influenced by the balance between them. ERSEM predictions demonstrate for the first time that limiting phosphorus in 2002 determines the structure of the phytoplankton community, which in turn constrains the structure and functioning of the planktonic food-web. In particular, model results confirm the observed evidence that a well-balanced N : P : Si nutrient enrichment, as observed in 2002, has a positive effect on the diatomcopepod linear food-chain, while the regenerated-based microbial food-chain sustained its basic level. The phosphate
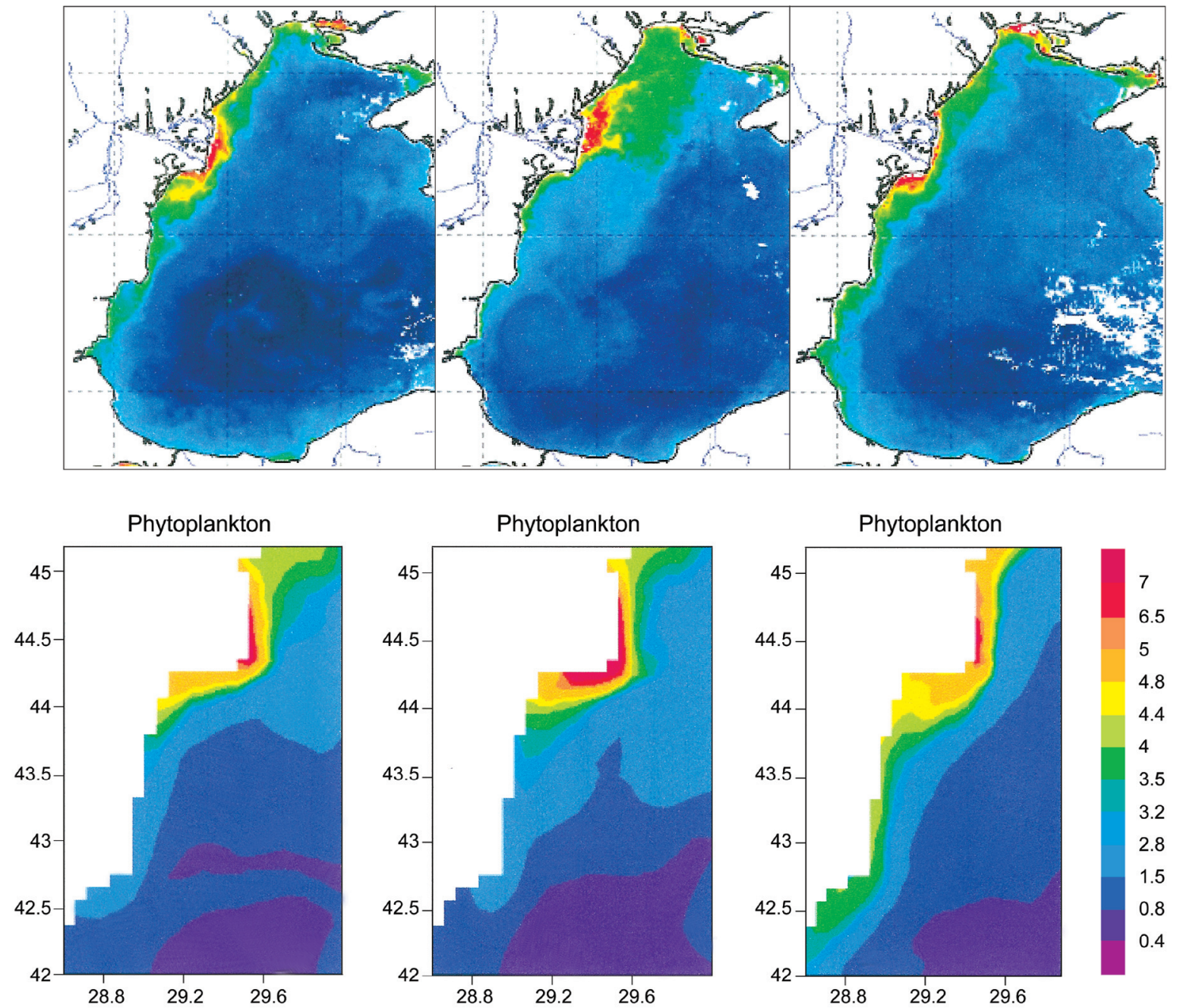

Fig. 17. Weekly mean chlorophyll-a from satellite data and model simulations (left column: 02 - 09 April 2003, middle column: 17 - 24 June 2003 , right column: 4 - 11 September 2003). 
(a)

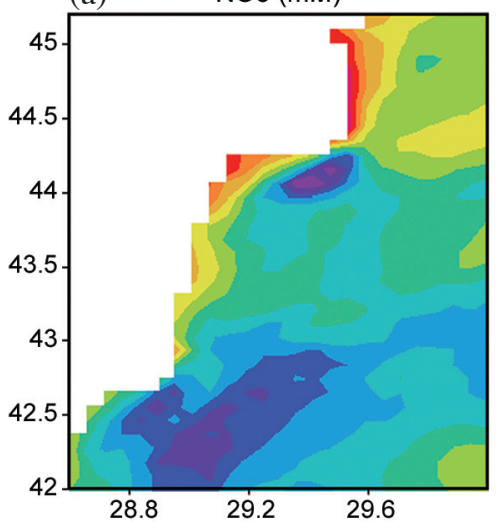

(b)

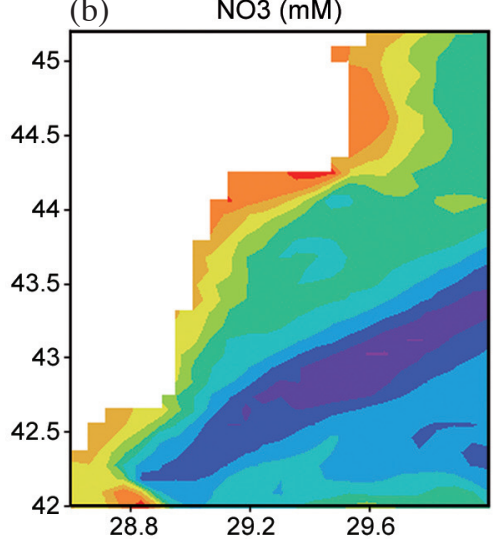

(c)

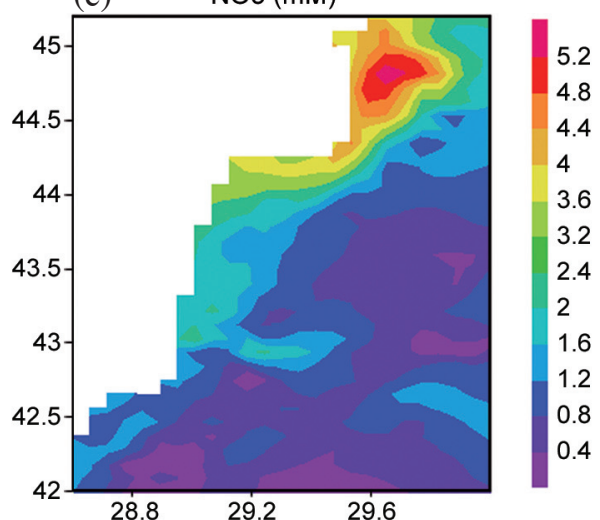

Fig. 18. Snapshots of model simulated horizontal distribution of nitrates (NO3) on (a) 20 March 2003, (b) 17 - 24 June 2003 , and (c) 4 - 11 September 2003).

(a)

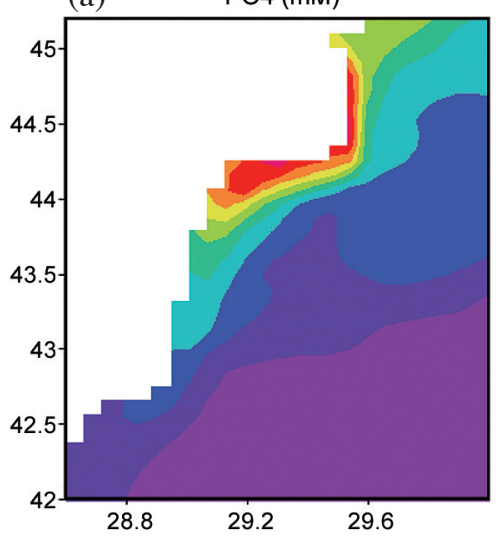

(b)

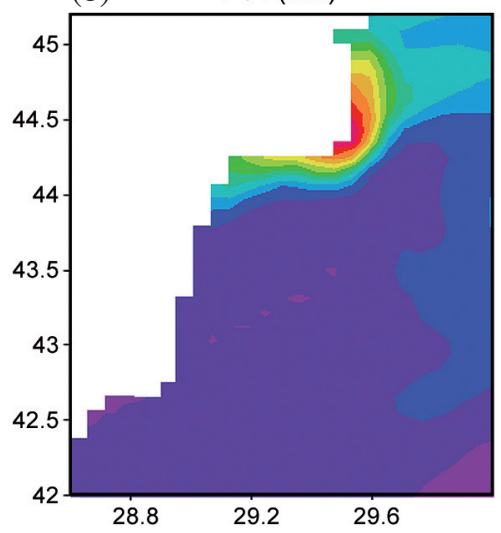

(c)

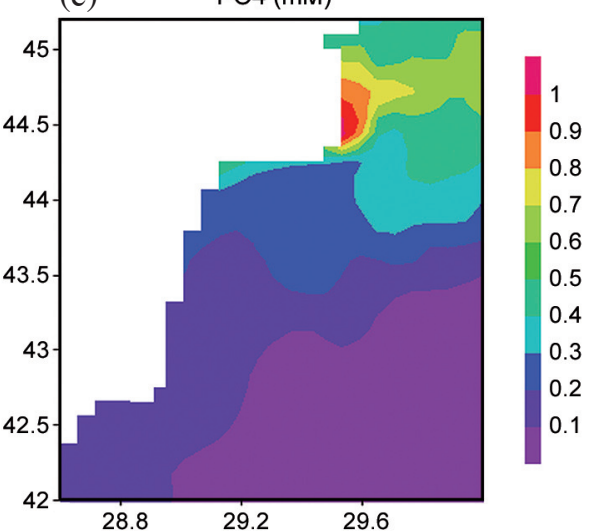

Fig. 19. Snapshots of model simulated horizontal distribution of phosphates (PO4) on (a) 20 March 2003, (b) 20 July 2003 , and (c) 20 October 2003.

limitation, on the other hand, directs the structure of the planktonic food-web towards the dominance of an active microbial food-web in which bacteria and microzooplankton play a key role, acting as a nutrient regenerator wherein the latter acts as a trophic path to the copepods and thence onward into the linear food-chain. In 2002 a "silicate-excess" Black Sea ecosystem was predicted by the model in a very good agreement with observed evidence and leading to the key conclusion that in the period of our realistic simulations phosphate rather than nitrogen constrains the structure and functioning of the Black Sea ecosystem. Therefore, the observed positive signs of recovery of the Black Sea ecosystem might well be related to the reduction of the Danube nutrient loads that are evident in ERSEM predictions, in a very good agreement with the field observations in Romanian and Bulgarian coasts in 2002.

Obviously the modifications and the combination of existing models prove essential to the success of the application of a high trophic level ecosystem model for the North-western Black Sea to describe its specific features as demonstrated by the analysis presented in the paper. One of the key components in the functioning of the Black sea ecosystem since 1986 is the jelly Mnemiopsis leydyi and since mid 90-ies the newly introduced jelly Beroe ovata. The predator-prey couple Mnemiopsis-Beroe plays an important role in the ecosystem trophic interactions. Thus it is very advisable for the next step of the model development to make some effort to include modules reflecting these interactions to further help to better match the model results with the field observations and minimise the deviation of the model results from the zooplankton data (Copepods) in August (the period of Mnemiopsis proloferation). Originally Mnemiopsis feeds on fodder zooplankton and is responsible for the reduction of zooplankton standing stock that represents an ecological concern. This is a challenging work in progress under the EU Integrated Project SESAME.

Acknowledgments The study is a contribution to the CEC Contract Fifth Framework Programme - Energy, environment and substantial development, Contract No. EVK1- 
CT-2000-00051: Nutrient management in the Danube basin and its impact on the Black Sea and a contribution to EU $6^{\text {th }}$ Framework projects SESAME (Contract No. 036949-2). We are grateful to Anastasios Papadopoulos from the Hellenic Center for Marine Research, who provided the 2002 - 2003 POSEIDON atmospheric fields, as well as, to Adrianna Cociacu of the National Institute for Marine Research and Development "Grigore Antipa", Romania and Violeta Velikova of the Institute of Fisheries and Aquaculture, Varna, Bulgaria, who provided us with in situ data. We are thankful to B. Gardeike from GRSS Research Center for improving the quality of some of the figures. We are also thankful to A. Davidov from the University of Kiel for providing SeaWiFS data.

\section{REFERENCES}

Allen, J. I., R. H. M. Howland, N. Bloomer, and R. J. Uncles, 1999: Simulating the spring phytoplankton bloom in the Humber plume (UK). Mar. Pollut. Bull., 37, 295305, doi: 10.1016/S0025-326X(98)00174-X. [Link]

Baretta, J. W., W. Ebenhoh, and P. Ruadji, 1995: The European regional seas ecosystem model, a complex marine ecosystem model. Neth. J. Sea Res., 33, 233-246, doi: 10.1016/0077-7579(95)90047-0. [Link]

Baretta-Becker, J. G., J. W. Baretta, and E. K. Rasmissen, 1997a: The microbial food web in the European Regional Seas Ecosystem Model. Neth. J. Sea Res., 33, 363-379, doi: 10.1016/0077-7579(95)90053-5. [Link]

Baretta-Bekker, J. G., J. W. Baretta, and W. Ebenhoh, 1997b: Microbial dynamics in the marine ecosystem model ERSEM II with decoupled carbon assimilation and nutrient uptake. J. Sea Res., 38, 195-211, doi: 10.1016/S1385-1101(97)00052-X. [Link]

Beckers, J. M., M. L. Grégoire, J. C. J. Nihoul, E. Stanev, J. Staneva, and C. Lancelot, 2002: Modelling the Danube-influenced Nort-western continrntal shelf of the Black Sea. I: Hydrodynamical processes simulated by 3-D and box models. Estuar. Coast. Shelf Sci., 54, 453472, doi: 10.1006/ecss.2000.0658. [Link]

Blackford, J. C. and P. J. Radford, 1997: A structure and methodology for marine ecosystem modelling. Neth. J. Sea Res., 33, 247-260, doi: 10.1016/0077-7579(95) 90048-9. [Link]

Blumberg, A. F. and G. L. Mellor, 1983: Diagnostic and prognostic numerical circulation studies of the South Atlantic Bight. J. Geophys. Res., 88, 4579-4592.

Broekhuizen, N., M. R. Heath, S. J. Hay, and W. S. C. Gurney, 1997: Modelling the dynamics of the North Sea's Mesozooplankton. Neth. J. Sea Res., 33, 381-406, doi: 10.1016/0077-7579(95)90054-3. [Link]

Bryant, A. D., M. R. Heath, N. Browkhuizen, J. G. Ollason, W. S. C. Gurney, and S. P. R. Greenstreet, 1995: Modelling the predation, growth and population dy- namics of fish within a spatially-resolved shelf-sea ecosystem model. Neth. J. Sea Res., 33, 407-421, doi: 10.1016/0077-7579(95)90055-1. [Link]

Cokasar, T. and E. Ozsoy, 1998: Comparative analyses and modelling for regional ecosystems of the Black Sea. In: Ivanov, L. and T. Oguz (Eds.), Ecosystem Modelling as a Management Tool for the Black Sea, NATO Science Series, Partnership Sub-Series 2, Vol. 47, Kluwer Academic, 323-358.

Constantinescu, A. and G. Menting, 2000: Ecological Gradients in the Danube Delta lakes: Present State and Man-Induced Changes, Chapter 3: Hydrology, DDNI and RIZA, Report 2000.015, ISBN 90.369.5309x, The Netherlands.

Ebenhöh, W., J. G. Baretta-Bekker, and J. W. Baretta, 1997: The primary production module in the marine ecosystem model ERSEM II, with emphasis on the light forcing. J. Sea Res., 38, 173-193, doi: 10.1016/S13851101(97)00043-9. [Link]

Eeckhout, D. V. and C. Lancelot, 1997: Modeling the functioning of the northwestern Black Sea ecosystem from 1960 to present. In: Ozsoy, E. and A. Mikaelyan (Eds.), Sensitivity to Change: Black Sea, Baltic Sea and North Sea, NATO Science Series, Partnership Sub-Series 2, Vol. 27, Kluwer Academic, 455-469.

Gill, A. and J. S. Turner, 1976: A comparison of seasonal thermocline models with observations. Deep-Sea Res. I, 23, 391-401, doi: 10.1016/0011-7471(76)90836-6. [Link]

Grégoire, M., J. M. Beckers, J. C. J. Nihoul, and E. Stanev, 1997: Reconnaissance of the main Black Sea's ecohydrodynamics by means of a 3D interdisciplinary model. J. Mar. Syst., 16, 85-105, doi: 10.1016/S09247963(97)00101-2. [Link]

Grégoire, M., K. Soetaert, N. Nezlin, and A. Kostianoy, 2004: Modeling the nitrogen cycling and plankton productivity in the Black Sea using a three-dimensional interdisciplinary model. J. Geophys. Res., 109, C05007, doi: 10.1029/2001JC001014. [Link]

Kourafalou, V. H., L.-Y. Oey, J. D. Wang, and T. N. Lee, 1996: The fate of river discharge on the continental shelf. Part I: Modeling the river plume and the innershelf coastal current. J. Geophys. Res., 101, 34153434 .

Kourafalou, V., K. Tsiaras, and J. Staneva 2004: Numerical studies on the dynamics of the Northwestern Black Sea shelf. Medit. Mar. Sci., 5, 133-142.

Lancelot, C., J. Staneva, D. van Eeckhout, J. M. Beckers, and E. Stanev, 2002: Modelling the Danube-influenced north-western continental shelf of the Black Sea. II: Ecosystem response to changes in nutrient delivery by the Danube River after its damming in 1972. Estuar. Coast. Shelf Sci., 54, 473-499, doi: 10.1006/ecss.2000. 0659. [Link] 
Lenhart, H. J., G. Rarach, and P. Ruadji, 1997: The effects of river input on the ecosystem dynamics in the continental coastal zone of the North Sea using ERSEM. J. Sea Res., 38, 249-274, doi: 10.1016/S1385-1101(97)00049X. [Link]

Mellor, G. L. and T. Yamada, 1982: Development of a turbulence closure model for geophysical fluid problems. Rev. Geophys. Space Phys., 20, 851-875.

Nesterova, D., S. Moncheva, A. Mikaelyan, A. Verishinin, V. Akatov, L. Boicenco, Y. Aktan, F. Sahin, and T. Gvarishvili, 2008: The state of phytoplankton. In: State of the Environment of the Black Sea (2001-2006/7), Approved by BSC for 2008, Black Sea Commission Publications, Istanbul, Turkey, $419 \mathrm{pp}$.

Oguz, T. and B. Salihoglu, 2000: Simulation of eddy-driven phytoplankton production in the Black Sea. Geophys. Res.Lett., 27, 2125-2128, doi:10.1029/1999GL011083. [Link]

Oguz, T., H. Ducklow, P. Malanotte-Rizzoli, S. Turgul, N. Nezlin, and U. Unliata, 1996: Simulation of annual plankton cycle in the Black Sea by a one-dimensional physical biological model. J. Geophys. Res., 101, 16551-16569.

Oguz, T., U. Unluata, H. W. Ducklow, and P. MalanotteRizzoli, 1999: Modeling the Black Sea pelagic ecosystem and biogeochemical structure: A synthesis of recent studies. In: Besiktepe, S. T., U. Unluata, and A. S. Bologa (Eds.), Environmental Degradation of the Black Sea: Challenges and Remedies, NATO Science Series, Partnership Sub-Series 2, Vol. 56, Kluwer Academic, 197-224.

Oguz, T., P. Malanotte-Rizzoli, and H. W. Ducklow, 2001: Simulations of phytoplankton seasonal cycle with multi-level and multi-layer physical-ecosystem models: the Black Sea example. Ecol. Model., 144, 295314, doi: 10.1016/S0304-3800(01)00378-7. [Link]

Papadopoulos, A., G. Kallos, P. Katsafados, and S. Nickovic, 2002: The Poseidon weather forecasting system: An overview. Global Atmos. Ocean Syst., 8, 219-237.

Stanev, E. V., J. V. Staneva, and V. M. Roussenov, 1997: On the Black Sea water mass formation. Model sensitivity study to atmospheric forcing and to parameterizations of some physical processes. J. Mar. Syst., 13, 245-272, doi: 10.1016/S0924-7963(96)00115-7. [Link]

Staneva, J. V. and E. V. Stanev, 1998: Oceanic response to atmospheric forcing derived from different climatic data sets. Intercomparison study for the Black Sea.
Oceanol. Acta, 21, 393-417.

Staneva, J. V. and E. V. Stanev, 2002: Water mass formation in the Black Sea during 1991-1995. J. Mar. Syst., 32, 199-218, doi: 10.1016/S0924-7963(02)00038-6. [Link]

Staneva, J. V., E. V. Stanev, and T. Oguz, 1997: The impact of atmospheric forcing and water column stratification on the yearly plankton cycle. In: Ivanov, L. and T. Oguz (Eds.), Ecosystem Modeling as a Management Tool for the Black Sea, NATO Science Series, Partnership Sub-Series 2, Vol. 47, Kluwer Academic, 301-323.

Staneva, J. V., V. H. Kourafalo, and E. V. Stanev, 2003: The response of the Black Sea ecosystem to changes of nutrient discharge from the Danube River. In: Yilmaz, A. (Ed.), Oceanography of the Eastern Mediterranean and Black Sea, Tubitak, Ankara, Turkey, 307-313.

Tsiaras, K. P., V. H. Kourafalou, A. Davidov, and J. Staneva, 2008. A three-dimensional coupled model of the western Black Sea plankton dynamics: Seasonal variability and comparison to SeaWiFS data. J. Geophys. Res., 113, C07007, doi: 10.1029/2006JC003959. [Link]

Van Gils, J., H. Behrendt, A. Constantinescu, K. Isermann, and M. Zessner, 2005: Future development of nutrient emissions and river loads in the Danube Basin. Proceedings of the River Basin Management Conference, 219-230, Budapest.

Varela, R. A., A. Cruzado, and J. E. Gabaldon, 1995: Modelling primary production in the North Sea using European Regional Seas Ecosystem Model. Neth. J. Sea Res., 33, 337-361, doi: 10.1016/0077-7579(95)900527. [Link]

Velikova, V., A. Cociasu, L. Popa, L. Bpicenco, and D. Petrova, 2005: Phytoplankton community and hydrochemical characteristics of the Western Black Sea. Water Sci. Technol., 51, 27-37.

Vichi, M., P. Oddo, M. Zavatarelli, A. Coluccelli, G. Coppini, M. Celio, S. Fonda Umani, and N. Pinardi, 2003a: Calibration and validation of a one-dimensional complex marine biogeochemical flux model in different areas of the northern Adriatic Sea. Ann. Geophys., 21, 413-436.

Vichi, M., W. May, and A. Navarra, 2003b: Response of a complex ecosystem model of the northern Adriatic Sea to a regional climate change scenario. Clim. Res., 24, 141-159. 